\title{
Tangut Tax Records
}

As a major pillar of Tangut economy, agriculture not only provided the lifeline of livelihood on which so many depended, but it also constituted the main source of tax revenue for the government. Indeed, tax levied on agricultural production was an indispensable income that sustained imperial, governmental, and military expenditures. In fact, the Chinese empire in the Central Plains likewise relied on agriculture for government spending, as "funding for the army and the state all comes from taxation."1 There are some, though very scare, Chinese documentation on the taxation system of Western Xia, mainly in the larger context of tax exemption in disaster relief. As mentioned in Chapter I, the Renzong Emperor approved his ministers' proposal to reduce or eliminate taxes for those injured in the great earthquake of Xingzhou (Yinchuan) and Xiazhou (Jingbian county, Shaanxi) in April of the fourth year of Daqing (1143):

In the two prefectures, in cases where lives are lost to the earthquake, two are compensated with exemption of taxes for three years, and one with waiver of taxes for two years; the injured are exempt from taxes for two years; let collapsed houses and walls be repaired by the relevant commission. $^{2}$

The abundance of historical sources on Tangut taxation, however, is found in the Laws of Heavenly Prosperity, the law code of the empire, and specifically in Book XV, which contains a list of items on agricultural taxes. Section titles reveal the classification of content in this chapter, such as "To Press for Payment" and "Misbehaviours and Merits in Pressing for Payment." The Tiansheng Laws require that:

Let the authority command the heads of the taxable households to register for their cultivated lands, including the size in qing and $m u$, the harvest in sheng and dou, as well as the amount of forage. Let staff members from the Bureau of Transfer and Transportation issue the owners of the

1 Ma, Duanlin. Wenxian Tongkao, “Tianfukao” [文獻通考 田賦考]: Comprehensive Examination of Literature (1317). Beijing: Zhonghua Book Company, 1986, "Examination of Farmland Taxes" Part 4, "Institutions of Taxation in Previous Dynasties."

2 Xixia Shushi, Ch. 35. 
properties their receipts, in order that the heads of the households pay the due amount according to the number indicated on the documents. ${ }^{3}$

The so-called head or owner of a household refers to a subject who legally owned farmlands under tax obligations. Peasants typically paid a variety of land taxes, which are fastidiously registered in official records. In the same section of the law code, it is indicated that late payments were subject to penalties:

In case the head of a household is liable for a variety of taxes on land, labour and forage, and yet delays the payment even when pressed by the authorities, let the concerned farmer and other members of his household be arrested, and based on the severity of the violations, let them be punished by the right number of strokes, and urged again to the speedy payment of their taxes. ${ }^{4}$

The Laws also require that each year, all prefectures and counties submit registers of land taxes and receipts to the Bureau of Transfer and Transportation on the first day of November. In late November, the staff at the Bureau of Transfer and Transportation would then deliver the records to the Bureau of Review (Mokansi) whose officials will proofread them within a month, in other words from the first day of December till the end of the month. Any delay in the review process would have implicated the governmental staff in criminal negligence. ${ }^{5}$ Book XVI in the Laws of Heavenly Prosperity also concerns agricultural taxes. Unfortunately, this volume of the manuscript survives only in fragments, so it is only possible for scholars to speculate on the original content based on the titles in the table of contents. Although a relatively large corpus of written records on Tangut agricultural taxation have survived to the twentieth century, for a while, scholars neither retained sources on the precise amounts paid nor fully understood the formality and materiality of the tax registration. The answer to these questions, however, has recently emerged from the cloud as new materials have appeared. A diverse range of tax records

3 Revised Laws of Heavenly Prosperity 15, "On the Miscellaneous Taxes of Irrigation for Farmland," p. 508. The text operates on a distinction between the idea of state-imposed 'rent' (i.e. taxes) on land leased out for farming, and the conventional notion of 'rent' as transferred in contracted use of land between and amongst households. "Household" in the context of the Revised Laws of Heavenly Prosperity refers to the farming households that pay land taxes to the state, rather than landowners who farm the land out, or tenants who sharecrop the land.

4 Revised Laws of Heavenly Prosperity 15, "On the Miscellaneous Taxes of Irrigation for Farmland," p. 508.

5 Revised Laws of Heavenly Prosperity 15, "On Urging the Payments of Taxes," p. 490. 
have recently been identified in the corpus of Khara-Khoto social documents, which now constitute the bulk of primary source on Tangut taxation. These texts not only offer a close look at the system of taxation in Western Xia but also open the gateway to inquiries on a wide array of social issues related to the Tangut economy.

\section{1 \\ Accounts of Agricultural Taxes}

In the Russian collection of Khara-Khoto manuscripts, Инв. No. 4808 is a $20.4 \times 575 \mathrm{~cm}$ hemp-paper scroll of signed grain taxes (by liliu and household) in 259 lines of cursive Tangut writings, comprised of four stitched fragments. The beginning and ends of the manuscript are missing, and two additional patches, one with six lines and the other with one line, are fractured. Furthermore, since the back of the manuscript is covered with the text of a Buddhist sutra, overlapping ink from the two sides have obscured some of the characters. The first two sections are statistical accounts of grains levied as taxes, while the third and fourth are registers of household grain taxes.

The following is a translation of the grain tax accounts of the first five households indicated in the third section (line $6-15):^{6}$

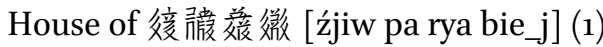

Barley 1 dan, 1 dou 5 sheng; wheat 2 dou, 8 sheng, 7.5 ge

House of chief? ?茒? [? wejr] (2)

Barley 4 dou 3 sheng; wheat 1 dou $7 \mathrm{ge}$ and a half

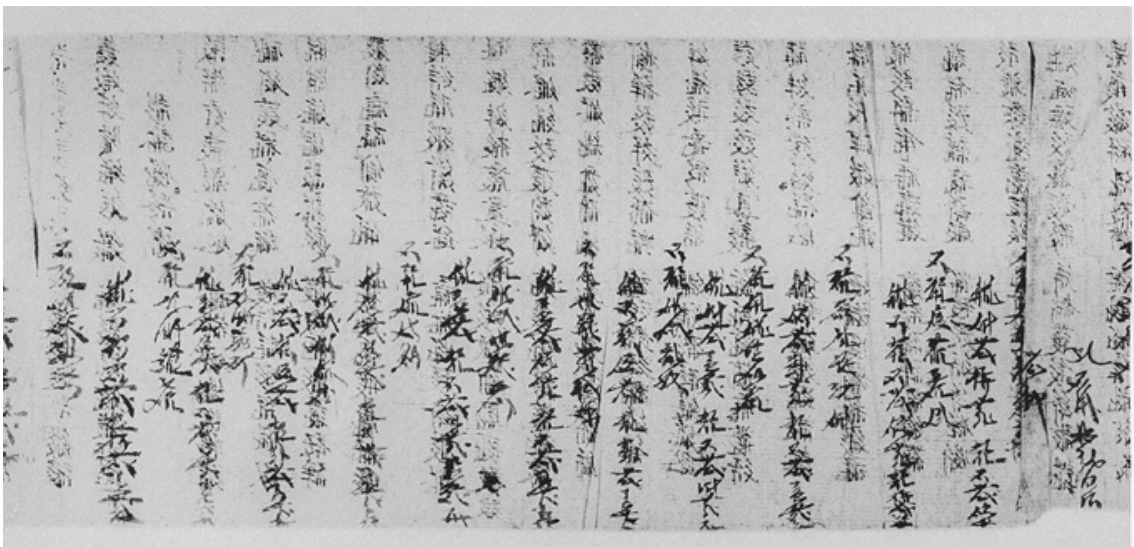

FIGURE 31 Инв. No. 4808 (6): Grain tax account

6 Russian Collection of Khara-Khoto Manuscripts 13, pp. 291-298. 


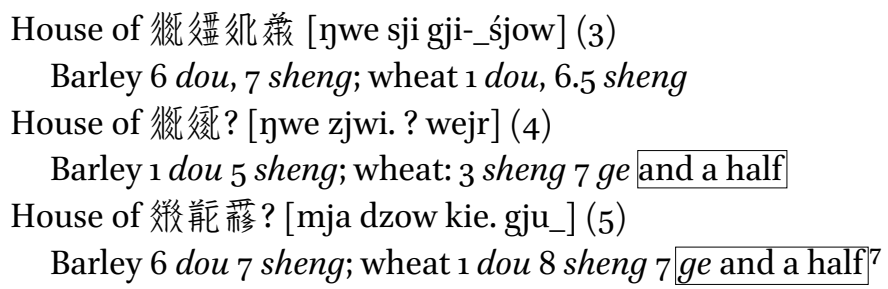

The five registers show that these Tangut households paid 'taxes-in-kind' in the form of barley and wheat, rather than in money. In fact, more than 20 households registered in this section pay taxes in these two kinds of grains. Indeed, the Tangut government designates different crops as taxes for the various regions of its territory. According to its laws:

Residents of the Lingwu county are obliged to pay wheat; Barley is levied on the Baojing county; both hemp and soybean are paid by the heads of households in Huayang county; the (glutinous) sorghum is levied on the residents of Linhe county; $S u$, the (foxtail) millet, is taxed from the Zhiyuan county; $M i$, the proso millet, is paid by the two counties of Dingyuan and Huaiyuan. ${ }^{8}$

The list of multiple kinds of crops and grains includes the taxes-in-kind paid by households in the larger area surrounding the imperial capital. Absent on this list are the kinds of grain taxes levied on faraway regions on the periphery of the empire, such as the city of Khara-Khoto. However, from the above manuscript, we have learned that the Tanguts in Khara-Khoto paid taxes in both barley and wheat. Similar texts also show that occasionally, taxpayers turned in proso millet along with barley and wheat. For historians, these primary sources shed light on the main types of agricultural produces in Khara-Khoto under Tangut rule.

If we pay close attention to the ratio of wheat to barley mentioned in the manuscript, it is easy to notice that the amount of wheat is roughly quarter that of barley. Although the bottom part of the text is not in good condition and the end digits of wheat statistics for households 1, 2, 4, and 5 are incomplete, the numbers of both crops in the case of household 3 is a clear indication of the ratio: 6 dou and 7 sheng of barley, 1 dou and 6.5 sheng of wheat. In other words, the amount of barley is almost precisely four times that of wheat. This evidence supports the hypothesis that the Khara-Khoto authorities levied the

7 Russian Collection of Khara-Khoto Manuscripts 13, p. 293.

8 Revised Laws of Heavenly Prosperity 15, "On Urging the Payment of Taxes," pp. 489-49o. 


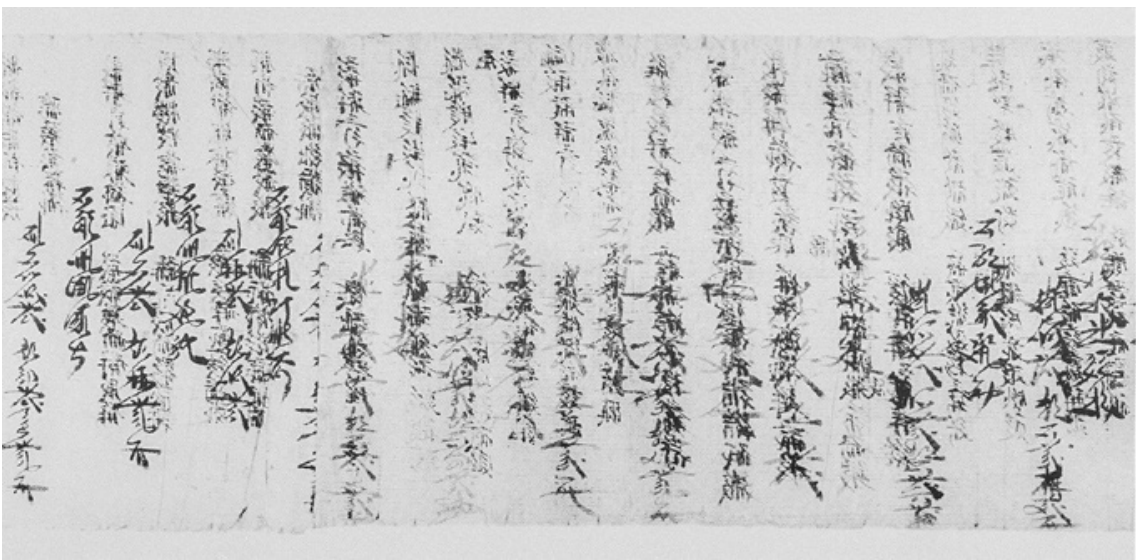

FIGURE 32 Инв. No. 4808 (9): Household grain tax accounts

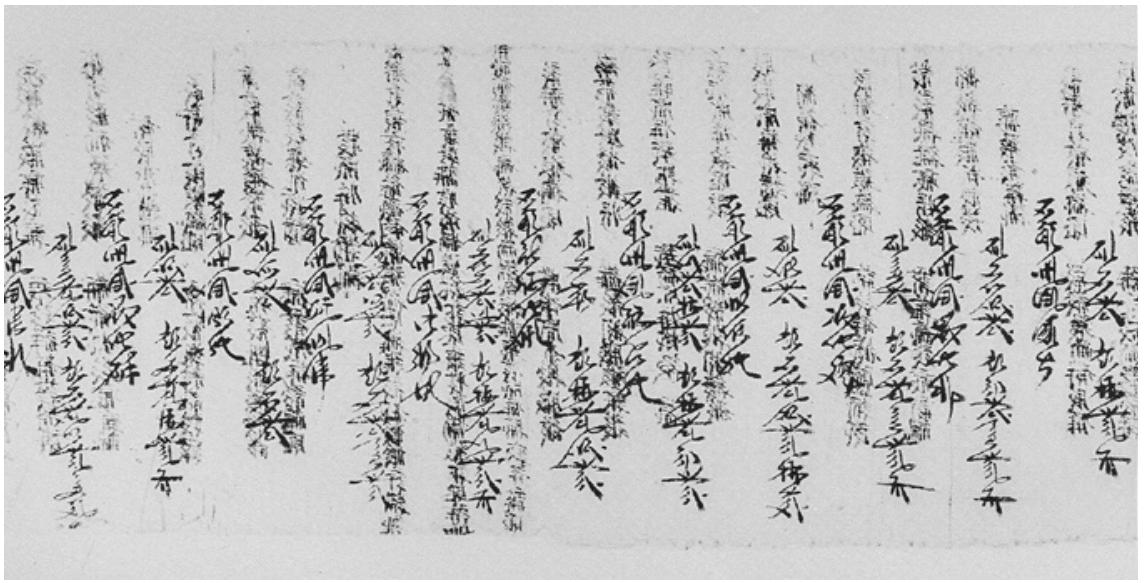

FIGURE 33 Инв. No. 48о8 (10): Household grain tax accounts

two grains from local households in the ratio of 4:1. If so, then it becomes also possible to speculate on the missing numbers in the manuscript. ${ }^{9}$

The fourth section of the same account features a different category of produce: (miscellaneous) grains.

The following is a translation of the first ten household registers in section 4 , Инв. No. 4808 (the last six lines of the first to the second image): ${ }^{10}$

9 The numbers within the soft brackets () are numerical orders of households added by the author for purposes of convenience and reference.

Russian Collection of Khara-Khoto Manuscripts 13, p. 295. 


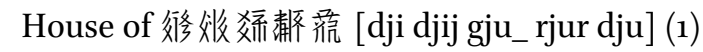

Grains 2 dou; wheat 5 sheng

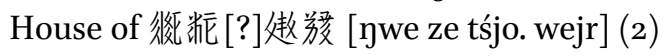

Grains 1 dou; wheat 2.5 sheng

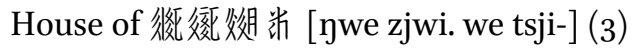

Grains 1 dan 5 dou; wheat 3 dou 7.5 sheng

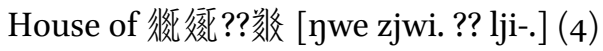

Grains 7 dou; wheat 1 dou 7.5 sheng

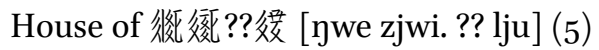

Grains 6 dou; wheat 1 dou 5 sheng 2 ge

House of 後鿉? [ jwe zjwi. ? wejr] (6)

Grains 9 dou 2 sheng; wheat 2 dou 3 sheng

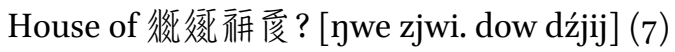

Grains 1 dan; wheat 2 dou 5 sheng

House of 䏤组?? [·jiw dji.j] (8)

Grains 1 dan, 1 dou, 8 sheng; wheat 2 dou 9.5 sheng

House of 煺瑑 (the blessed)?? (9)

Grains 6 dou 8 sheng; wheat 1 dou 7 sheng

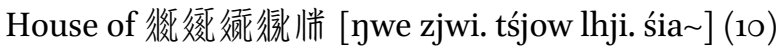

Grains 4 dou, wheat 1 dou

The ten households indicated above, and another 50 or so, pay the so-called (miscellaneous) grains in addition to wheat. The 'grains' might have been simply another term for barley, for the grain to wheat ratio in all 9 houses was 4:1, with only the fifth house paying an additional $2 \mathrm{ge}$ of wheat, possibly due to calculation or transcription errors. This account registers crop taxes by the unit of distance, liliu. With some margin of error in the case of the fifth house as mentioned above, the account of taxes paid by up to 18 houses confirms the grain to wheat ratio to be about 4:1.

Similar social documents include the Инв. No. 1222 and 1460-1. From these manuscripts, we know the actual amount of taxes-in-kind that each household paid but not the category of tax nor tax rate. Another kind of document offers some insights to answer these questions.

Инв. No. $1755^{-4}$ is a fragment page of a grain tax document. This $16.8 \mathrm{~cm} \times 31.9 \mathrm{~cm}$ hemp paper with damages on all four sides contains the following 14 lines in Tangut cursive: 


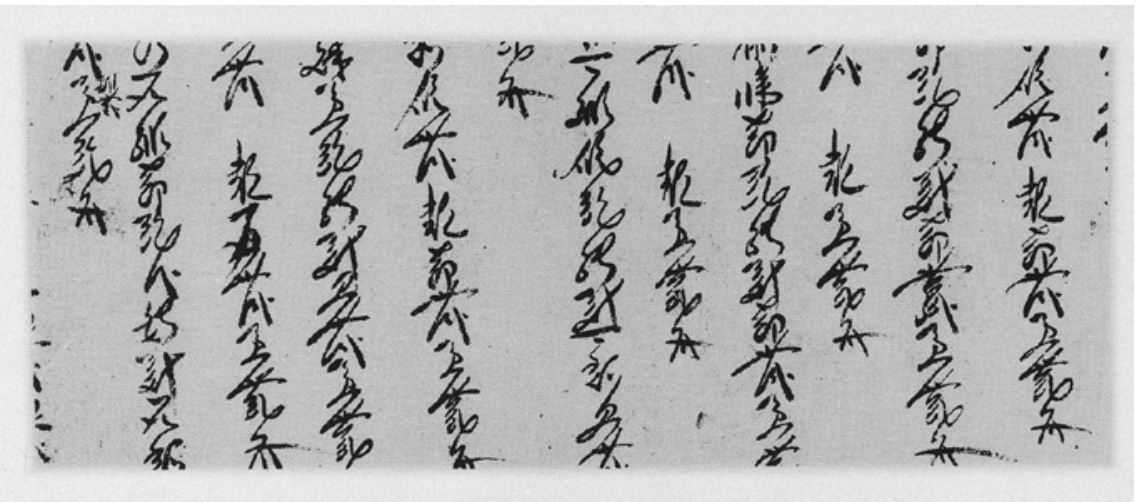

FIGURE 34 Инв. No. 1755-4: Account of grain tax by land size

Translation:11

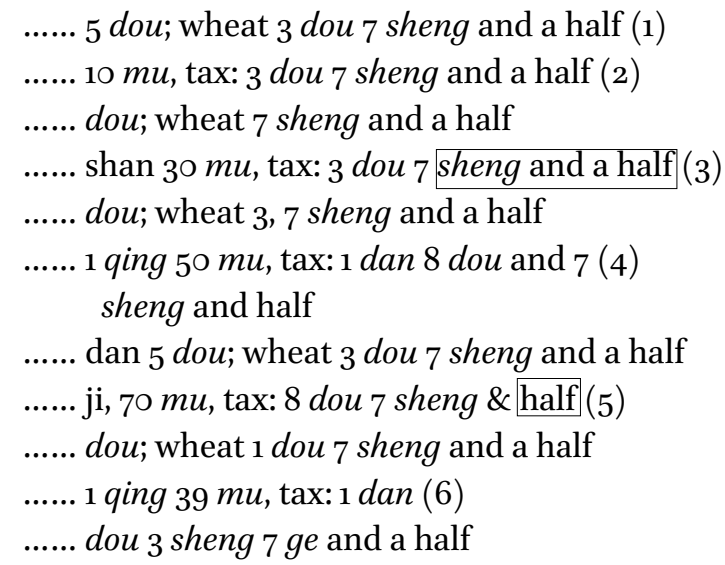

This text documents the size of the farmland and the amount of grains paid as tax-in-kind. Quite obviously, this is a grain tax account by the size of household-owned land. Line 1 is in fact the last line in the register of household \#1; lines 2-3 are the tax account of household \#2; lines 4-5 correspond to household \# 3 ; lines 6-8, household \#4; lines 9-10, household \#5; lines 11-12, household \#6. Most names of the household heads are missing, but the first character in line 4 for 'hill,' and 'fortune' in line 9 are what remains of two such names. With the imperfect data on tax and land size, it is now possible to calculate the rate of taxation by farmland. Take household \#4 as an example. The

11 Russian Collection of Khara-Khoto Manuscripts 12, p. 306. 
family owns $15 \mathrm{O} \mathrm{mu}$ of land and pays one dan, eight dou and seven and a half sheng of grains as tax. Although the precise number of assorted grains are lost, there remain the characters for "... dan 5 dou" and "(taxed) wheat 3 dou 7 sheng and a half." With the performance of a simple deduction of the wheat taxed (3 dou, 7.5 sheng) from the total crops taxed (1 dan 8 dou and 7.5 sheng), we arrive at the number of assorted grains taxed as 1 dan and 5 dou, which matches the remnant information in the manuscript (the indication of 'dan' before and the absence of any remainder in sheng or ge after the $5 \mathrm{dou}$ ). If we then divide the tax by the size of the land, it is possible to gain the tax rate at o.1 dou (i.e. 1 sheng) of assorted grains and 0.025 dou of wheat (i.e. a quarter of sheng) per $m u$ of land. This tax rate is confirmed in the data on land and grains from other households. The moral of this story is the existence of a well-enforced system of agricultural taxation in the Western Xia, by which the grains are levied in proportion to the size of house-owned farmland. The discovery of this well-documented institution of fixed tax rates generates significant insights on Tangut agriculture. It shows at least that the Tanguts inherited the land tax system typical of the imperial institution of taxation in many dynasties.

Furthermore, once the tax rate is ascertained, it becomes possible to regain access to the numbers on both land and grain now missing in manuscript Инв. No. $1755^{-4}$, and thus to expand the text to a total of 14 lines:

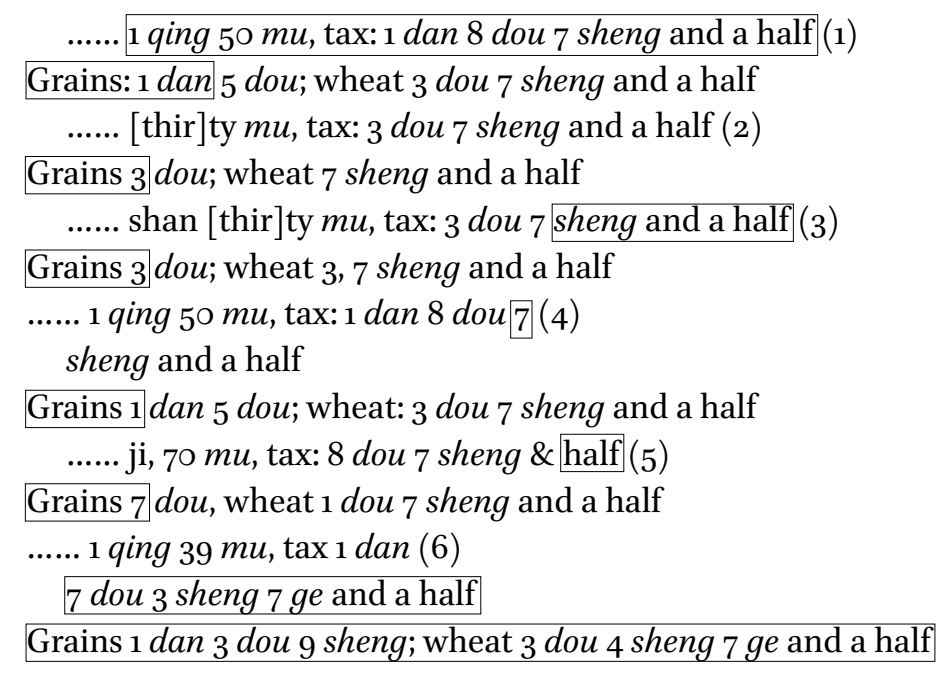

There exist numerous similar accounts of grain taxes by land size, such as the manuscript Инв. No. -2-1. This $12.9 \times 31.8 \mathrm{~cm}$ document is originally a layering paper for a book cover. The text features an upper and lower section of grain tax registers in fragments. The lower part contains grain tax accounts of seven 


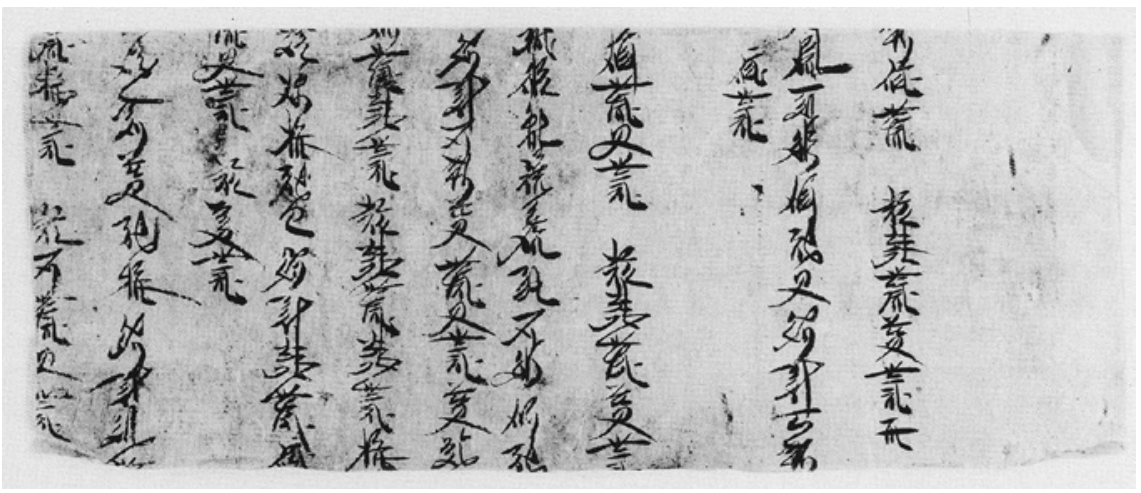

FIGURE 35 Инв. No. 1178-2: Account of grain tax by farmland size

households in 12 lines of Tangut cursive writings, but the tax payment registers are missing. Another example is the $12.7 \times 32.3 \mathrm{~cm}$ manuscript Инв. No. 1178-2, with its 11 lines in Tangut cursive scribbled over another layering paper of a book cover. ${ }^{12}$

Translation of the text with emendation:

...... Grains 1 dan 5 dou; wheat 3 dou 7 sheng and a half (1)

le 1 qing $48 \mathrm{mu}$, tax: 1 dan dou (2)

5 sheng

Grains 1 dan 4 dou 8 sheng, wheat 3 dou 7 sheng ......

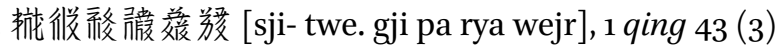

$m u$, tax: 1 dan 7 dou 8 sheng 7 ge \& a half

Grains 1 dan 4 dou 3 sheng; wheat 3 dou 3 sheng 2

...... ji, $28 \mathrm{mu}$, tax: 3 dou 5 sheng (4)

Grains 1 dan dou 8 sheng; wheat 7 sheng

...... you, $72 \mathrm{mu}$, tax: 9 dou (5)

Grains 7 dou 2 sheng; wheat 1 dou 8 sheng

The calculated tax rates for household \# 1,2, 4, and 5 are identical to the standard rate that was calculated based on data from the previous manuscript: one sheng of grains and about a fourth of sheng of wheat per mu of land. In the lone of household \#3, however, the wheat count is three dou 3.2 sheng, which could have been a calculation or transcription error from the correct amount of three dou, five sheng, and 7.5 ge. Indeed, an additional number of grain-to-land tax accounts such as Инв. No. 324-2, 5809-2 and 5940 demonstrates consistency

12 Russian Collection of Khara-Khoto Manuscripts 12, p. 211. 
in the grain tax rate that we have determined, with a result that deviations from the number may be treated as minor mistakes or discrepancies. Scholars are also able to conclude that the manuscript Инв. No. 4808, which only shows the number of crops taxed but not the size of farmland, to be likewise a grain-to-land tax account.

According to the Laws of Heavenly Prosperity, those who clear wastelands for agriculture in the peripheral regions of the empire are exempt from taxes for three years: "after three years, if the area proves arable, then three sheng of miscellaneous grains are taxed for one $m u$ of land."13 It then seems that the tax rate applied to local communities in Khara-Khoto was lower than the rate for newly-farmed lands as indicated in the code of law. But it is also worth noting that the agricultural taxes in Khara-Khoto are not necessarily representative of those in the majority of areas in Western Xia. Consider another set of rules and regulations in the same Laws of Heavenly Prosperity where the government may apply an adjusted measure of grain-to-land taxation in the areas surrounding the imperial capital: the farmlands concerned are sorted into five ranks based on quality, with a slightly modified tax rate for each. As a result, the tax rate sometimes exceeds that in Khara-Khoto by a significant margin.

Concerning the taxpaying households in the seven neighbouring counties near the imperial capital, lands are ranked according to their fertility: the highest, 1 dou; the second best, 8 sheng; the middle, 6 sheng; the lower, 5 sheng; the bottom, 3 sheng; hence a total of 5 ranks. ${ }^{14}$

It is not difficult to see the underlying message of this piece of legislation: the fertile and irrigable lands near the imperial capital are progressively taxed, at

13 Revised Laws of Heavenly Prosperity 15, "On Land Taxes," pp. 495-496.

14 Russian Collection of Khara-Khoto Manuscripts 8, pp. 300, 307, 301. Only the second half of this item is published in Professor Kychanov's Russian edition of the Revised Laws of Heavenly Prosperity (Изменённый и заново утверждённый кодекс девиза царствования Небесное проиветание, 1149-1169) Vol. 4. Three earlier leaves were missing. Nor is the missing half present in the Chinese edition (Shi, Jinbo, et al.) of the Revised Laws of Heavenly Prosperity. However, the missing piece was discovered amongst the manuscripts in Russia, just in time for the Sino-Russian collaboration in the publication of the Russian Collection of Khara-Khoto Manuscripts. In another unfortunate turn of events, page 2 in Volume 8 of the Russian Collection of Khara-Khoto Manuscripts was mistakenly placed at the end. See Pan, Jie. "Tiansheng Gaijiu Xinding Lüling Cuijiaozumen Yiduan Xixiawen Zhuihe” [天盛改舊新定律令.催繳租門一段西夏文緅合]: “Conjoining a piece of Tangut writing in the Section on Urging the Payment of Taxes in the Revised Laws of Heavenly Prosperity" in Ningxia Shehui Kexue [寧夏社會科學]: Ningxia Social Sciences, issue 6, 2012. 
some rates much higher than in Khara-Khoto in order to extract maximal government revenues.

Agricultural taxes in Western Xia are hardly limited to the fixed grain-to-land imposts. According to the Law of the Heavenly Prosperity:

All the counties are obliged to transfer the imposts, so they are required to urge and monitor the payment of levies on land, labour and forage. They are then supposed to collect all the receipts, one round per month, to be fetched by appointed officials and delivered to the Transfer Commission. ${ }^{15}$

In fact, there are more than a few accounts of taxes on land, labour, and forage in the corpus of Tangut economic records. Altogether, they document all three kinds of taxes that sustained the imperial revenue.

\subsection{Land, Labour and Forage in Tax Accounts}

The term 'land tax' is captured by the Tangut character 终 [zji.j], which means 'rent' and 'tax.' It refers both to the 'rent' that a taxpayer submits to the state, and to the lease rent that any private farmer has to pay the landowner. In this context, however, it means the land tax levied by the empire. The Tangut character for 'labour' is 桱 [tśju], an equivalent of the Chinese character '役, which literally means 'occupation.' In the context of the Laws of Heavenly Prosperity, the word is customarily translated as 'employment' (i.e., the service of labour contributed to a particular project), which may be an extension of the Song-era Chinese term for 'employment, “職役."16 As for 'forage,' or 'hay' in particular, the Tangut word is that for 'grass' 駢, or the bundles of hay levied as a tax-in-kind. The tax laws cited at the beginning of the section convey a very clear message: The Tanguts paid not only crops in proportion to their lands and harvests, but also labour services and forages. According to the regulations of agricultural profits in Book 16 of the Laws of Heavenly Prosperity, there are

15 Revised Laws of Heavenly Prosperity 15, "On the Miscellaneous Taxes of Irrigation for Farmland," pp. 507-508.

16 Pan Jie changed the translation of 'employed labour' to 'taxed labour,' which is adopted in this book. See Pan, Jie. “Xixia Zuyicao Kaoshu” [西夏租役草考述]: “A Critical Survey of Tax, Labour, and Hay in Western Xia" (unpublished manuscript). 


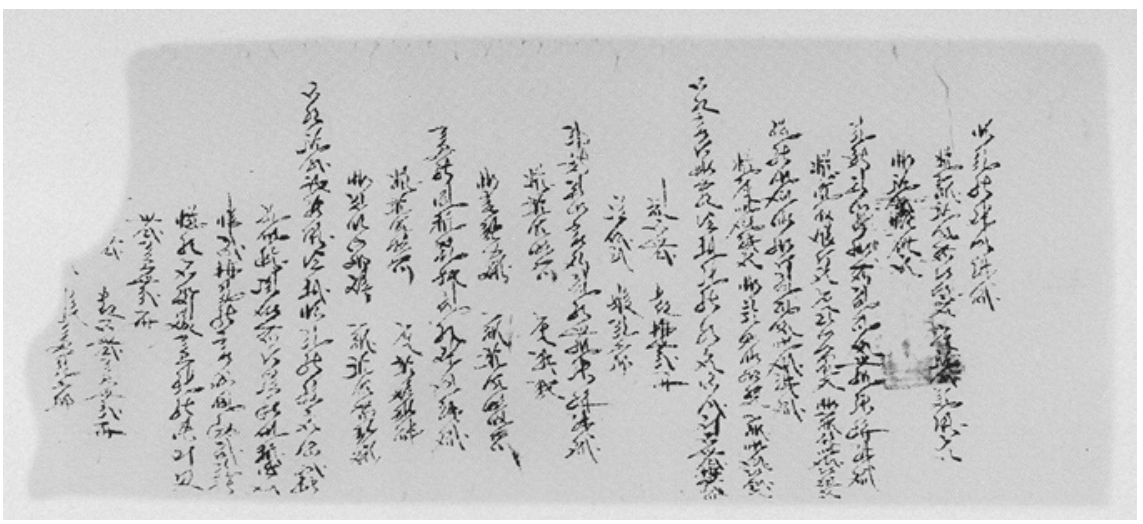

FIGURE 36 Инв. No. 4067: Household account of farmland and labour taxes

items that specify the procedures of "landowners' registration of taxes," "the forage obligations of farmers in the Mingsha and imperial capital" and "the distribution of ryegrass duties to the farm owners." Although the content of these legislations remains unknown to scholars, for none of the relevant manuscripts have survived to this day, it is now possible to catch a detailed and realistic glimpse of the land, labour and forage taxes through the lens of excavated Tangut social documents.

The manuscript Инв. No. 4067 is a tax payment account on a piece of $19.5 \times 46.2 \mathrm{~cm}$ hemp paper. Although the beginning and end are both missing, there are 23 lines of legible Tangut in the cursive style, which provide data on three households: their payment of taxes, location and boundaries of owned lands. The only register preserved in complete form is in the middle. The first 3 of its 9 lines (lines 8-16) concern the size of land and amount of tax, whereas the next 6 lines describe the locations and boundaries of the two farmlands owned by this house. ${ }^{17}$

The following is a translation of three lines $(8-10)$ on the land and tax:

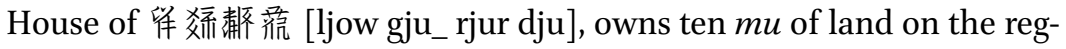
ister; tax: 1 dou 2 sheng and a half

Miscellaneous grains 1 dou; wheat 2 sheng and a half

Labour services: 5 days; forage: 10 bundles of hays

The land-to-grain tax rate here is patently identical to the calculated number in the previous sections: For $10 \mathrm{mu}$ of land, a tax rate of 1 sheng (o.1 dou)/mu

17 Russian Collection of Khara-Khoto Manuscripts 13, p. 180. 
yields a total payment of 1 dou of tax; as for wheat, $10 \mathrm{mu} \times 0.025 \mathrm{dou} / \mathrm{mu}=$ 0.25 dou $=2.5$ sheng. But this account differs from what has been seen so far in that it lists 5 days of labour services and 10 bundles of hay. This rule in the Laws of Heavenly Prosperity states:

When large or small-scale labour projects take place within and at the borders of the realm, let labourers be gathered and dispatched according to law. If labourers are not sent, in violation of the law, let a man of status be punished with the confiscation of a horse, and a commoner by thirteen strokes. ${ }^{18}$

There were a wide variety of labour services in Western Xia. The government drafted labourers to construct and repair canals and to transport goods and provisions across the territorial domain of the vast empire. Labourers summoned to work were scattered at the end of the project. If an unfinished assignment required the continued service of labourers, the government asked for and approved a special report on the status of the commission. The household listed above offered five days of services, which is about the amount of labour required for a year.

The manuscript Инв. No. 5067 is a tax record of the same kind, written on the back of a Buddhist sutra. Despite damages in the beginning and at the end, the $19.2 \times 238 \mathrm{~cm}$ long scroll features a total of 119 lines of Tangut in the cursive. The section on each household's land and labour tax begins at the top without indentation, followed by lower indented lines on the names of the household patriarch, changes in land conditions, the current size of cultivated lands, as well as the total amount of grains taxed. The final two lines rise up two spaces, which record the numbers of mixed grains, wheat, labour (in days) and hay (in bundles) in four parts. Occasionally, this section also documents the location and four boundaries of the piece of farmland concerned. ${ }^{19}$

Of the 14 household records, \#1 suffers an illegible beginning and a loss of information on land size, while households \#2, \#9 and \#12 seem to have sold their lands, hence the absence of records on their payments of land, labour and forage taxes. The other 10 households, however, have complete sets of records sufficient for us to calculate and analyse the relationship between land and labour taxes.

18 Revised Laws of Heavenly Prosperity 7 , "On Conducting Taxed Labour," p. 288.

19 Russian Collection of Khara-Khoto Manuscripts 14, pp. 5-7. 


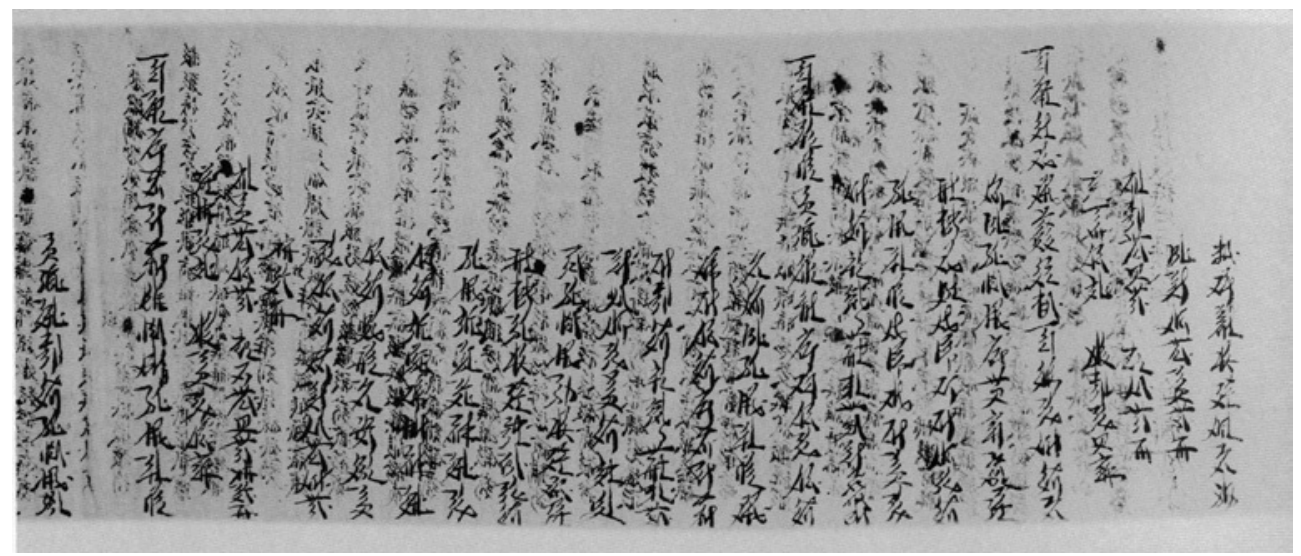

FIGURE 37 Инв. No. 5067 (1): Household account of farmland and labour taxes

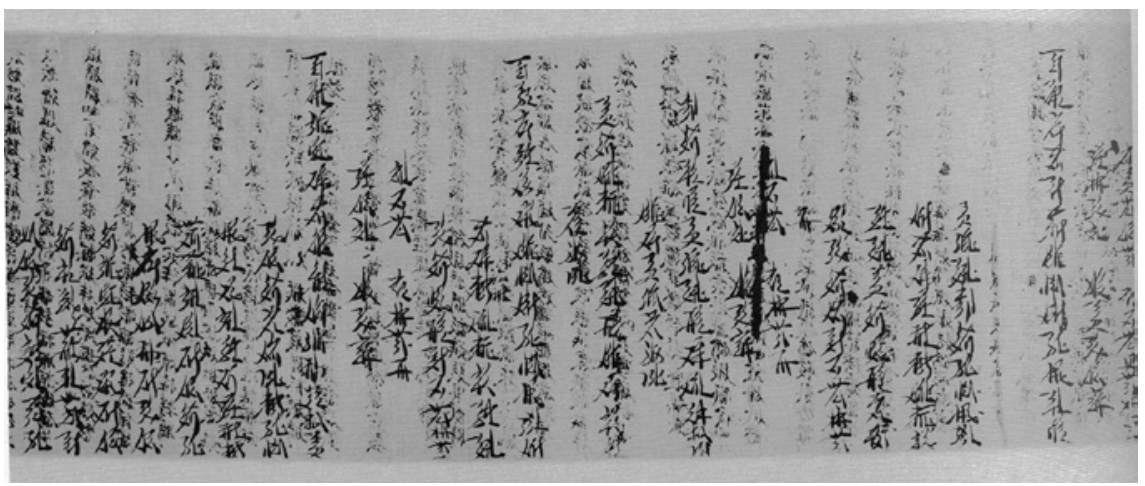

FIGURE 38 Инв. No. 5067 (2): Household account of farmland and labour taxes

The following is a translated excerpt of Инв. No. 5067 on the land size (in $m u$ ) and labour service (in days) of the ten households:

Household \# 3 : land $75 \mathrm{mu}$, labour service 20 days;

Household \#4: land $10 \mathrm{mu}$, labour service 5 days;

Household \#5: land $10 \mathrm{mu}$, labour service 5 days;

Household \#6: land $38 \mathrm{mu}$, labour service 15 days;

Household \#7: land 1o $\mathrm{mu}$, labour service 5 days;

Household \#8: land $35 \mathrm{mu}$, labour service 15 days;

Household \#10: land $73 \mathrm{mu}$, labour service 20 days;

Household \#11: land $63 \mathrm{mu}$, labour service 20 days;

Household \#13: land $15 \mathrm{mu}$, labour service 15 days;

Household \#14: land $40 \mathrm{mu}$, tax levied 15 days. 
At first glance, owners of ten $m u$ of land typically contributed five days of labour. Fifteen days of work, however, correspond to a range of land sizes, from 15 to 35,38 and $40 \mathrm{mu}$. Those who owned 63,73 and $75 \mathrm{mu}$ of land paid 20 days of labour. In general, land size and labour output are positively correlated. It is likely, therefore, that the amount of labour taxes was also partly determined by land ownership.

Labour service as a form of taxation is mentioned in the statements on springtime canal constructions in the Laws of Heavenly Prosperity:

For taxable households within the vicinity of the imperial capital, which contribute to the great canal construction in the spring, those who own 1-10 $m u$ of land work for 5 days; owners of 11-40 mu of land, 15 days; 41-75 $\mathrm{mu}, 20$ days; 75-100 $\mathrm{mu}$, 30 days; from $100 \mathrm{mu}$ to 1 qing and $20 \mathrm{mu}$, 35 days; from 1 qing and $20 \mathrm{mu}$ to 1 qing and $50 \mathrm{mu}$, 40 days. Days are calculated based on land size in qing and $m u$. Those who fulfil the requirement sooner may be released of their duty earlier. ${ }^{20}$

The law stipulates that for the canal-building project in the spring, each household unit is to contribute labour services for five varying lengths of duration: $5,15,20,30,35$ or 40 days, respectively. The numbers indicated in the law code agree with the data from the manuscript studied above, except for the lack of examples for 35 and 40-day periods. However, this is partly compensated, by a similar record, Инв. No. 7415-1, a $20.5 \times 28.9 \mathrm{~cm}$ manuscript account of household land, labour and forage tax also marred at the two ends. Its first two lines indicate a tax amount of 1 dan, 1 dou and 2 sheng of miscellaneous grains, which allow us to calculate the land size to be 1 qing and $12 \mathrm{mu}$. This family paid "1 month and 5 days of labour service" - exactly 35 days. ${ }^{21}$

Yet another land, labour and forage tax of the same type deserves our attention. The $19 \times 37.5 \mathrm{~cm}$ Russian manuscript Инв. No. 5252 contains 22 lines of cursive Tangut, despite loss of information at the two fronts. One of the households recorded in this document (see lines 10-15), which owns 1 qing and $50 \mathrm{mu}$ of farmland, pays 1 dan and 5 dou of assorted grains, 3 dou 7.5 sheng of wheat, as well as "one full range" of labour. ${ }^{22}$

\footnotetext{
20 Revised Laws of Heavenly Prosperity 15, "On the Affairs of Opening Canals in the Spring," pp. 495-496.

21 Russian Collection of Khara-Khoto Manuscripts 14, p. 177.

22 Russian Collection of Khara-Khoto Manuscripts 14, p. 30.
} 


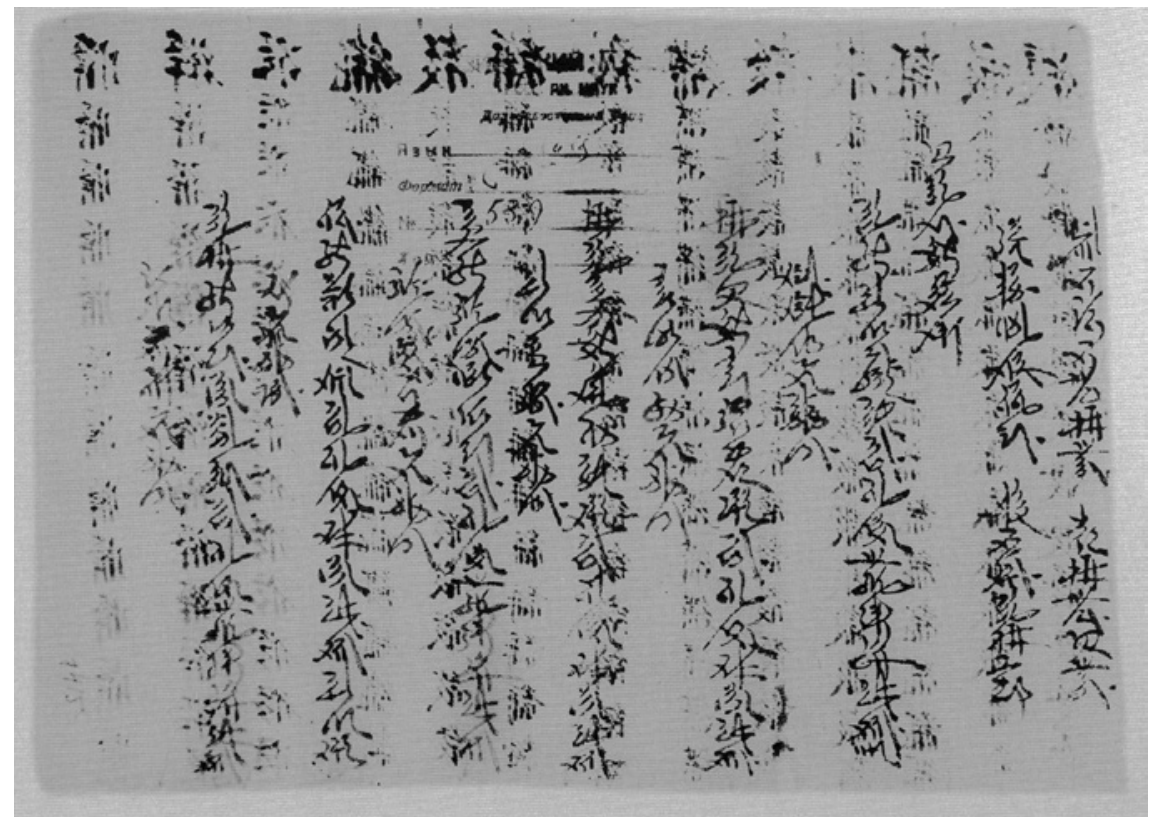

FIGURE 39 Инв. No. 7415-1: Household account of land, labour and hay taxes

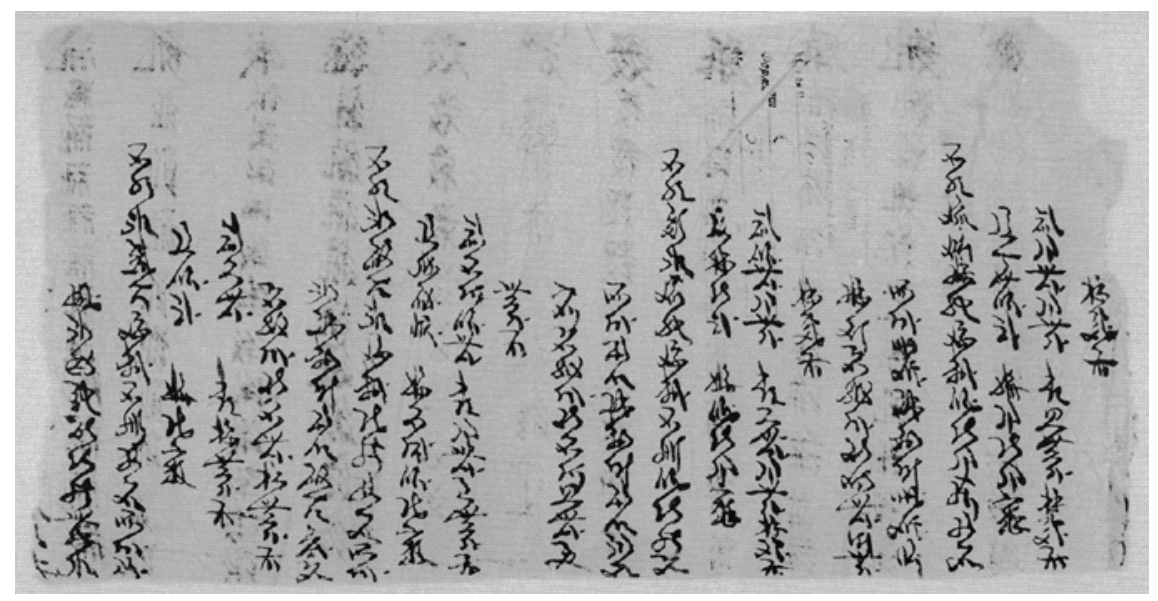

FIGURE 40 Инв. No. 5252: Household account of farmland, labour and hay taxes 
In the above two cases, the amount of labour contribution at 35 days and 40 days, respectively, coincides expectedly with the legal requirement in the Laws of Heavenly Prosperity that "owners of anywhere between $100 \mathrm{mu}$ and 1 qing and $20 \mathrm{mu}$ of land are obliged to offer 35 days of service. As for owners of as much land as between 1 qing and $20 \mathrm{mu}$ and 1 qing and $50 \mathrm{mu}$, they are required to contribute a full range of 40 days." Basically, the manuscripts convey the critical information that the 'labour service' as meant in the Khara-Khoto documents referred to the same tax obligation as the 'burden of labour' in the context of springtime canal construction around the imperial capital, as mentioned in the text of the Laws of Heavenly Prosperity. This type of tax payment in the form of manual labour was therefore not unique to the area in close proximity to the Tangut royal house; it was also present in peripheral, albeit important, territories like the city of Khara-Khoto.

As referenced repeatedly before, a critical portion of Tangut taxation consisted of 'forage,' which refers to the supply of hay used to feed horses both on domestic pastures over the harvestless wintry days of the year and in the cavalries and transport teams of a marching army. The importance of forage demands no redundant elaborations, given the important status of pasturing and animal husbandry in the economy of Western Xia. Besides, Tangut agriculture could not flourish without ample irrigation, which required a thick layer of hay underneath the canal pathways in the time of spring. For this variety of reasons, the Laws of Heavenly Prosperity mentions not only land, livestock and grains as household properties, but also 'bundles' (of hay), such as in the statement that "in cases of men who accidentally set on fire livestock, houses, persons, grains and foods, or bundles of hay, it is necessary to investigate and ascertain the actual amount of property losses." ${ }^{23}$ It is not surprising, then, for the same law code to also require the payment of tax-in-kind not only in terms of rents and labour but also forage, in very specific units of bundles which are determined based on the size of land ownership:

For each taxable household, apart from the winter reed clumps and summer herbs, all the other types of plants grown in its land are taxed at the rate of $5 \mathrm{chi} / \mathrm{mu}$ as a bundle; for $15 \mathrm{mu}, 4 \mathrm{chi}$ in pampas grass, willow branches and vines are all taxed by the amount of 1 bundle. ${ }^{24}$

Here is a list of the 10 households' land ownership and bundles of hays paid as tax:

23 Revised Laws of Heavenly Prosperity 8, "On Burning, Injuring, and Murdering," pp. 292-293.

24 Revised Laws of Heavenly Prosperity 15, "On Water Canals," p. $5 \circ 3$. 
Household \#3, land: $75 \mathrm{mu}$, hay: 75 bundles; Household \#4, land: $10 \mathrm{mu}$, hay: 10 bundles; Household \#5, land: $10 \mathrm{mu}$, hay: 10 bundles; Household \#6, land: $38 \mathrm{mu}$, hay: 38 bundles; Household \#7, land: $10 \mathrm{mu}$, hay: 10 bundles; Household \#8, land: $35 \mathrm{mu}$, hay: 35 bundles; Household \#10, land: $73 \mathrm{mu}$, hay: 73 bundles; Household \#11, land: $63 \mathrm{mu}$, hay: 63 bundles; Household \# 13, land: $15 \mathrm{mu}$, hay: 50 bundles; Household \# 14, land: $40 \mathrm{mu}$, hay: 40 bundles.

With the exception of household \#13, the 1:1 land-to-hay ratio remains consistent. As for the data on household $\#_{13}$, the $15 \mathrm{mu}$ of land v. 50 bundles of hay: Could it be the land size or the hay data that are erroneous? Fortunately, we have the amount of grain taxes under the same household, which reads " 1 dou, 8 sheng, $7 \mathrm{ge}$ and a half." Given the tax rate of 1 sheng, 2.5 ge/mu in Khara-Khoto, the household's owned land is calculated to be exactly $15 \mathrm{mu}$. It is therefore safe to say that the land size is correct, whereas the hay data suffered some typological or statistical error. Again, this analytical exercise demonstrates that the Tangut laws on hay taxes were thoroughly enforced even in remote territories.

The Laws of Heavenly Prosperity also stipulates:

For the heads of households to distribute the duties of ryegrass to the farmers, apart from the winter grass turfs and the rafters from their own land, for each qing and fifty $\mathrm{mu}$ of land, there is a duty of seven bundles of ryegrass and thirty bundles of millet grass. The rope bound to the bundles should be four chi and five cun in length. Additionally, they should place three $h u$ of wheat Brans in the bag of each bundle..$^{25}$

The Tangut classifier for 'bundle' (of grass, hay, forage, etc.) is 佫 [śja]. Originally a verb meaning 'to bind, or to fasten with a rope,' it evolved into a unit of measurement, signifying the result of the verbal action. This law specifies that for the $150 \mathrm{mu}$ of land, in addition to the allocated amount of winter grass and beams, there were an additional 37 bundles of rye and millet grasses. It is quite likely that a 1:1 ratio, namely 1 bundle of hay per $1 \mathrm{mu}$ of land, was the 'original' requirement as referenced here in the background, while the additional 37 bundles were amendments posterior to the era of Tiansheng. Tangut bureaucrats imposed fastidious requirements on the size of bundles by standardising

25 Revised Laws of Heavenly Prosperity 15, "On Urging the Payment of Taxes," p. 490. 


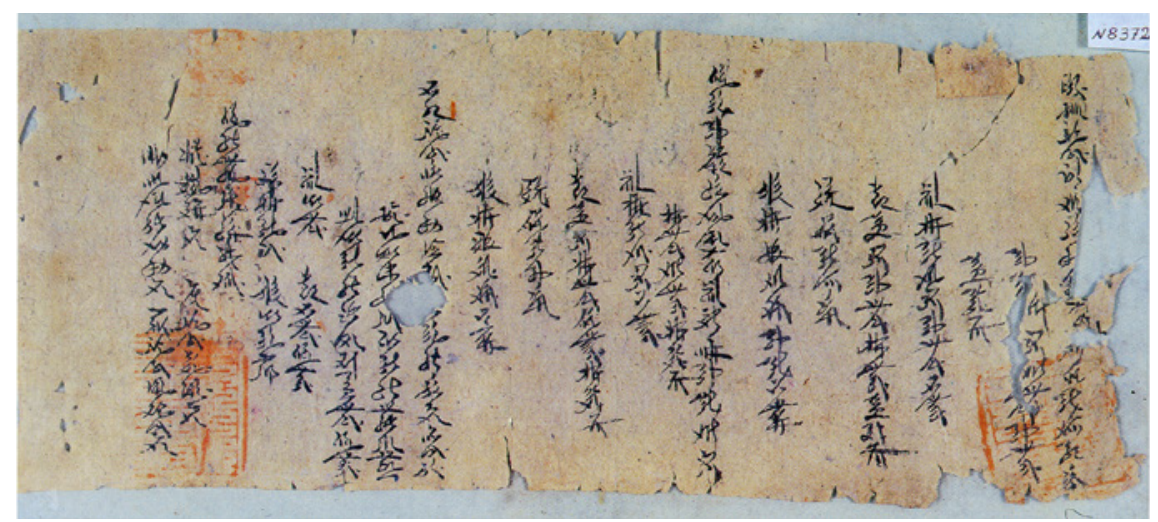

FIGURE 41 Инв. No. 8372: Household account of farmland, labour and hay taxes

the lengths of ropes used to bind them. Likewise, the Jurchens also required, in addition to the standard tax rate per $m u$ of land, an additional string of stalk (left in the plant after threshing), whereby each 'string' had to weigh 15 jin. The stalks (Chinese: 秸) are the straws of the crops. In that sense, what the Tanguts referred to as ryegrass and millet grass were also 'stalks' or 'straws.' The only difference between Tangut and Jurchen legislations is that the former measured by the length of the attached rope, whereas the latter did so by weight.

The Khara-Khoto tax records also show that the accounts of land, labour and hay taxes were registered by units of farming households. The statistical registers are, in turn, organised by the spatial unit of liliu. Тhe Инв. No. 8372 manuscript is a $19.5 \times 49 \mathrm{~cm}$ tax account with 21 lines of Tangut in the cursive style. There is some damage at the front and missing parts near the end. Additionally, the document features three red stamps. ${ }^{26}$

The following is a translation:

Liliu 效?? [tśhjiw zjwi.] a total of 54 households, taxes 16 dan 6 dou 3 sheng

7 ge and a half

Coarse, 29 dan 3 dou 1 sheng

Wheat 7 dan 3 dou 2 sheng 7 ge and a half

Labour 54 persons

Hay 2,931 bundles 
53 farming families? Farmers have fine/coarse grains, in total 36 dan 2 dou 6 sheng 2 ge and a half

Coarse 29 dan 1 dou

Wheat 7 dan 2 dou 5 sheng 2 ge and a half

Labour 53 persons

Hay 2901 bundles

Household 緮? [tśhjiw zjwi. tśhjwor], registered 6o mu of land on records; with ?? all

??large or small size? $10 \mathrm{mu}$ already

And 60 mu already retained, tax 7 dou 5 sheng

Coarse 6 dou wheat 1 dou 5 sheng

Labour 20 days hay 6 o bundles

$5 \mathrm{mu}$ connected to the canals

To the east to "Bird"? (border) To the south, to ...(border)

To the west, to “Prosperity of the Sixth Month" (聄很榎) (border); To the north, to 效? [tśhjiw zjwi. wa] (border)

This document registers 54 households within a unit of liliu. Unfortunately, the farmland (size and border), tax and hay statistics of only one household survives, leaving all other data missing. According to the Laws of Heavenly Prosperity, the administration of one liliu oversaw the management of 100 households. However, this manuscript shows that only 54 families fell into this liliu. In the case of the other document mentioned above, Инв. No. 6342, the liliu unit was comprised of 79 households. Therefore, more than one document seems to support the hypothesis that, notwithstanding the "10o households per liliu" requirement on government papers, the actual number of households within each liliu fluctuated from one area to another, depending on the realities of the area. But in any case, it was permissible for a liliu to have a smaller population than required in the law code.

Despite quite a few obstacles, including lost, blurred, and illegible characters and figures, it is possible to tell from the document that the 54 households turned in a total of $36 \mathrm{dan}, 6 \mathrm{dou}, 3$ sheng and $7 \mathrm{ge}$ and a half. Amongst them, coarse grains made up for $29 \mathrm{dan}, 3 \mathrm{dou}$ and 1 sheng, in addition to $7 \mathrm{dan}, 3 \mathrm{dou}$, 2 sheng and $7 \mathrm{ge}$ and a half of wheat. We also know that there was a total of 29 qing and $31 \mathrm{mu}$ of farmland. 54 individuals paid taxes by physical labourthat is, most likely, 1 person per household. As for how many days they toiled, however, there are no details. The documents record a total payment of 2,931 bundles of hay, which is also the accurate number based on the size of the 
farmland in $m u$. If 54 households turn in 36 dan, 6 dou, 3 sheng and 7 ge and a half of grains, whereas 53 households are taxed 36 dan, 2 dou, 6 sheng and 2 ge and a half, the difference in tax of one-unit household is $3.75 \mathrm{dou}$. Given that the Khara-Khoto government levied 1.25 sheng of grains per $m u$ of land, the household in question should have owned about $30 \mathrm{mu}$ of farmland. Besides, we also know that the 54 households turned in 2931 bundles of hay or grass, which is 30 bundles more than the total amount levied on the 53 households (2901 bundles), for 1 more household. Therefore, the tax in hay also proves that the one household owned $30 \mathrm{mu}$ of land. Unfortunately, because of damages to the manuscript fragment, it is impossible to identify what exactly set this one household apart from the other 53. One may conjecture many possibilities such as, for example, that this household was that of a lowlier family of shijun (semi-slaves).

Tax-in-kind was one of the main forms of tax levied on the agrarian populations of Western Xia. Not unlike in the Central Plains, tax-in-kind was the predominant regime of agricultural taxation. Another form of tax was physical labour. In Western Xia, corvée labour was used to build, renovate and manage canals. Given lower degrees of circularity in the Tangut currency, most of the taxes as referred to in the Khara-Khoto manuscripts were in terms of taxesin-kinds. Very few of these documents record taxes in cash or in real currencies.

\section{$2.2 \quad$ Receipts of Grain Taxes}

Amongst the British manuscripts of Khara-Khoto, Or. 1238o-2349 (k.k.), an $11 \times 8.5 \mathrm{~cm}$ block-printed document with filled-in characters, is a fragment with few remaining words - some clear, others pale or blurred — on both sides of the paper. ${ }^{27}$

Close scrutiny reveals the following in the first line on the first page: "Now from ..."; in the second line, (unclear characters in the block print) filled out in black ink, "interest due Barley ..."; in the third line, the block-printed characters read, "Tiansheng," whilst the part handwritten in black ink states, "twenty," followed by what may be inferred as "year"; the third line also has the following block-printed content: "office agent (sili) Yehe ..." Of course, the Tiansheng era falls into Emperor Renzong's reign, and Yehe is a Dangxiang Tangut family name. This government employee holds the office of an agent, or sili, with a seal

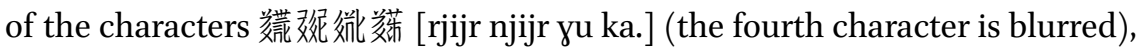
which literally translates into "measure/calculate, aspect/dimension, head, monitor/supervise,"- that is, a "junior accounting magistrate." Undersigned

27 These two images are photographed by the author. See also, British Collection of Khara-Khoto Manuscripts, p. 8o. 


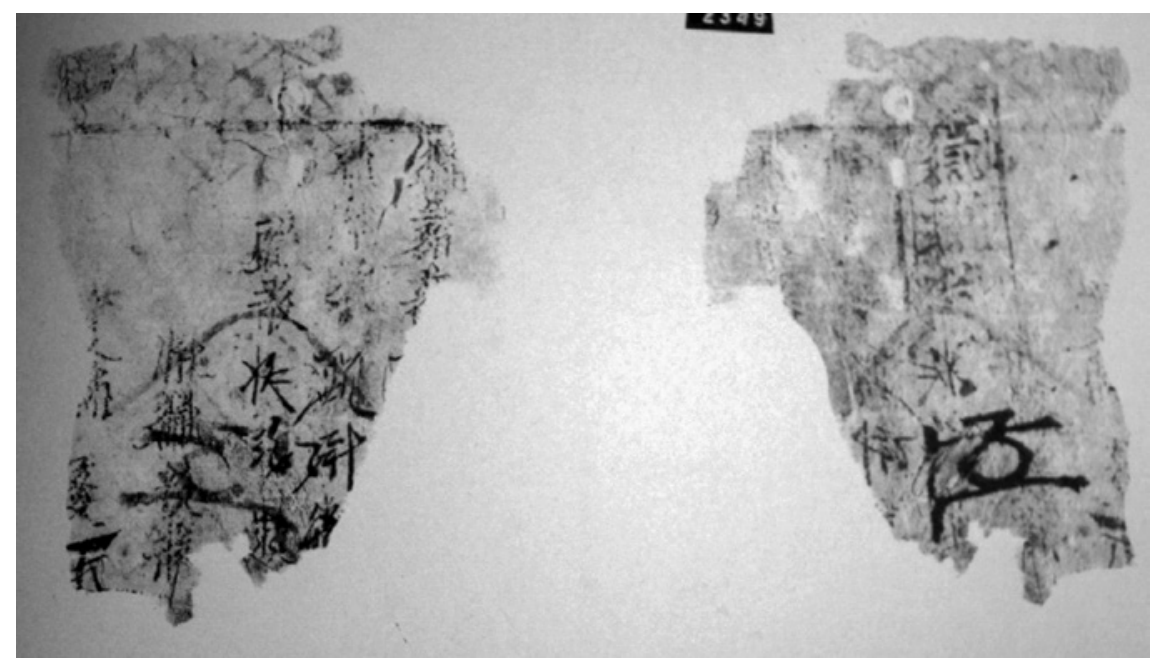

FIGURE 42 British Or. 1238o-2349 (k.k.): twentieth year of Tiansheng (1168) grain tax receipt

is a printed sign. Concerning the "junior accounting magistrate," the Laws of Heavenly Prosperity states:

When it is time for the collection of various taxes, the junior accounting magistrate should sit at the gate of the storage house. The patrolling magistrates should sit by the side of the junior accounting magistrate. They should call the names of those paying grains as taxes, in due order, and then measure what they offer before taking them over. They should also issue receipts to the taxpayers, which label the total sums in $h u$ and dou, and the signatures of the junior accounting magistrate. Any adulteration or falsification in the payment of grains is strictly forbidden. If the junior accounting magistrate and the patrolling magistrate from higher or lower offices are unable to check the amounts with accuracy, the local prefects in charge should take over the responsibility of supervision. If there is any violation of law-for instance, if those who did not pay are listed as having paid - and if there is inflation or falsification of the numbers, let the sum of the unpaid amount of grains be calculated, and let the culprit be tried on the charge of theft. If officials commit bribery, then the gravity of this offence is to be compared to the charge of 'Violation of Law and Corruption,' and whichever is more severe is to be applied to the culprit. If the concerned personality is not bribed, but rather committed errors in examinations and calculations, he is to be punished by the confiscation of a horse if an official, and by thirteen strokes if a commoner. 
And:

In addition to and alongside the old register book, the junior accounting magistrate is responsible for compiling a new book of statistics, according to the amount of grains taxed. Upon completion, he is obliged to compare the new book to the old, to ensure there is no inaccuracy or discrepancy. At the end, he should prepare a volume of clean copy to be attached to the memorial submitted to the Central Secretariat. The staff members within the Central Secretariat are expected to examine the records for yet another time. Should there be any discrepancy, let them report it to the Crown, and then proceed according to what instructions they receive. If the information matches, then let the new and old registers be preserved at the Central Secretariat, and let the additional copy be returned to be informed and delivered to the relevant offices in charge. ${ }^{28}$

This "junior accounting magistrate" in the passages above was a kind of tax-collecting agent in offices of local governments. As he received grains from the farming families in the area, he issued receipts with the amount of grains taxed and his own handwritten signature.

The document features the expression "interest due," handwritten here in this text. It essentially refers to the taxes. This word also appears multiple times in the Laws of Heavenly Prosperity, especially in the table of contents in the sixteenth volume. All the more regrettable, then, that the main content of that volume has been lost. So, there is practically no easy access to the specific legal items related to "interest due." However, the table of contents provides some clues. The sixteenth volume refers specifically to the notion of "due interest" for as many as 17 times: "On the Interests Due by the Peasants" includes "interest due' to holders of the plough in the ditches and in the field," "interest due' to holders of the plough in the border lines," "Sums of 'interests due' for royal provision of rice," "interests due' to holders of the plough," "interest due' to farm owners affiliated with the Department of Construction etc. holding their ploughs," “interests due' on hemp plantations, etc.," "Urging the payment of 'due interests,'” "Urging the examination of 'interests due' on the day of tax payment," "Urging the examination of 'due interests' in the border regions," "due interests' unable to enter the account," "Commuted sentence after no longer being able to wear shackles on charges related to 'due interests,"” "Political promotion rewarded for competency in managing grains and 'due interests," "the

28 Revised Laws of Heavenly Prosperity 15, "On the Dispatchment of Junior Accounting Magistrate to Collect Taxes in the Form of Grains," pp. 513-514. 
amount of 'interests due' to the farm owner," "The method of examining 'interest due' on ploughed fields," "failure to bring about the grains by the office in charge of collecting the 'due interests." From these terms and items, especially "Urging the payment of 'due interests," it is possible to surmise that "interest due" refers to the taxes that people pay to the government. Since the word for "barley" appears under the "interest due" in these texts, one could also infer and conclude that the taxes-in-kind are paid in terms of barley. Therefore, this manuscript is properly entitled "Receipt of grain tax payment in the twentieth year of Heavenly Prosperity (1168)."

The laws and regulations as they appear in the Laws of Heavenly Prosperity also match the content of these unearthed documents. The twenty or more characters on this manuscript, despite severe damages, once again testify to the efficiency, expediency and enforceability of the Laws of Heavenly Prosperity. ${ }^{29}$ Moreover, the grain tax receipt itself is an invaluable piece of textual material. There are multiple reasons for this, but one, at least, is the format of the document. The receipt is block-printed en masse, to be filled out by hand at a later time. Ground-breaking for its own time, this method renders the structure of the document fixed in format, systematic in scaled production, and thus more convenient for use, operation and management, despite their large quantity. It represents a major development in the ancient and medieval history of economic documents.

\subsection{Receipts of Increased Taxes on Bundles of Hay}

Some manuscripts shed light on additional impositions of taxes in bundles of hay. Amongst the manuscripts unearthed from the Haimu Cave in Wuwei, Gansu, there are two copies of a record on additional hay taxes, dated to the You Year of Qianding Reign (1225). The G31.05[6730]-[6731] are single pages on hemp paper, which measure up to $17.5 \times 13 \mathrm{~cm}$ and $19 \times 13.5 \mathrm{~cm}$ in size, respectively.

Both pages of the two documents are both printed with Tangut characters. At the front left corner of the front page, there is a large Tangut character inked in the standard script 㣪 [kow], which translates into the Chinese 官, meaning political office. This may be seen as the symbol that marks the nature of a document, not unlike official letter heads in modern formats of

29 This document was published for the first time in 2010. See Shi, Jinbo. "Yingcang Heishuicheng Wenxian Dingming Chuyi ji Buzheng” [英藏黑水城文獻定名芻議 及補正]: “A Preliminary Proposal for Naming and Amending the British collection of Khara-Khoto manuscripts" in Xixiaxue [西夏學]: Tangut Studies, No. 5, September 2010. Additional findings and insights on the nature and interpretation of the text are herein supplied. 


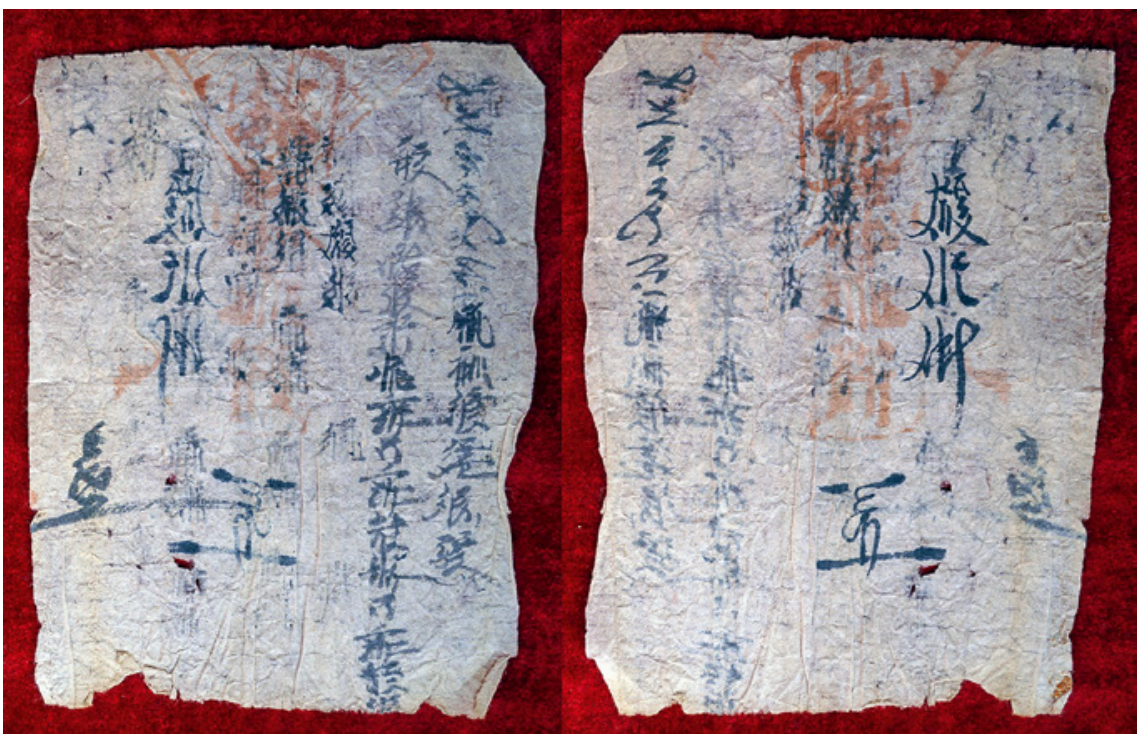

FIGURE 43 Wuwei manuscript G31.05[6730]: You year of Qianding, additional levies of hay in bundles, "government" document (front and back)

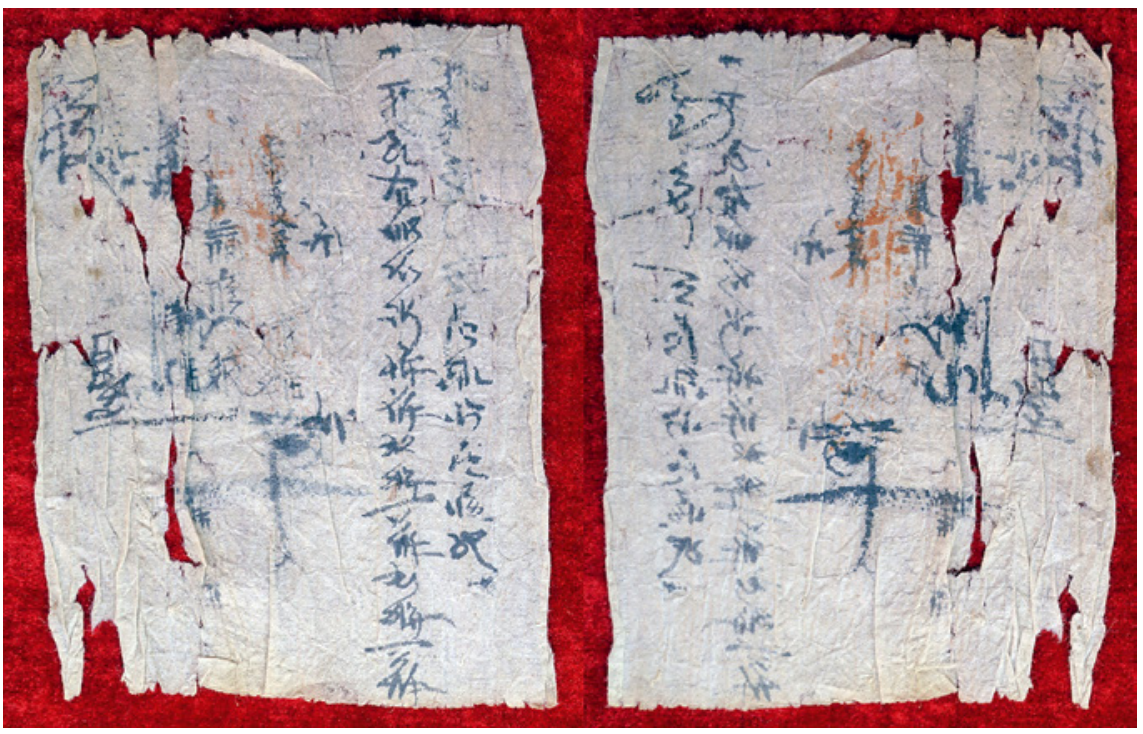

FIGURE 44 Wuwei manuscript G31.05[6731]: You year of Qianding, additional levies of hay in bundles, "household" document (front and back) 
political documents. On the back, there is a large character 䍳 [ya], also inked in standard script Tangut, which can be translated into the Chinese character 戶, meaning house, household or family.

The 㣪 $[\mathrm{kow}$ ] document begins with two lines of handwritten Tangut in the cursive script, which roughly translates as follows:

The head of the Liliu, Moxi "Prosperous sprout"

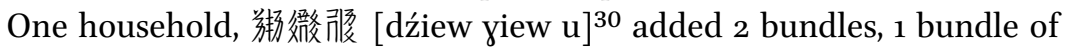
ryegrass, 1 bundle of millet grass.

Five lines of characters are printed at the end of this text:

You Year of Qianding Reign month day

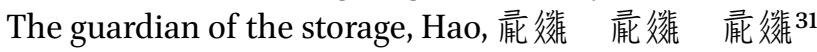

The one who made the official book of registers, Zhong

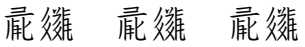

The guardian of the storage house, 䨿效

The document is sealed in red with a stamp of carved-in characters. The shape resembles an inverted triangle, and the words are unfortunately illegible. But from the inklings of what remains, it is possible to tell that the seal was originally square in shape, its four sides about $5.7 \mathrm{~cm}$ in length each. The size and format of this seal comes very close to the standard for the seals of Tangut chiefs.

There are two lines of Tangut in the cursive style on the back of the document. The first line reads: 唁很㗥 [dźjwow kjiw xo], "You Year (the year of Chicken) of" followed by formal prints. The four standard-script Tangut characters in the $10.5 \times 2.8 \mathrm{~cm}$ rectangular seal at the centre of the page are identified as 䵊萑微苯 $\left[\mathrm{khju}_{-} \cdot \mathrm{u}\right.$. yu ka.], the main officer in charge of the storage house.

Another document, the manuscript $\mathrm{G}_{31.05}\left[6_{731}\right]$ features 5 lines of Tangut on the front, which also begins with two lines handwritten in the cursive script. Apart from the different names which appear under "One household" in the second line, the rest of the content is almost identical. There are an additional 5 printed lines, which are so light and blurred that they cannot be fully

30 These three characters seem to be the name of a person. The first character is the family name 糼 [dźiew]. The next two characters are cursive and illegible. One guess based on

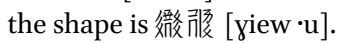


identified. But again, from what remains, it seems quite similar to the 㣪 document mentioned above.

Both documents record the officer in charge of this liliu district by the fine name of Moxi "the Prosperous Sprout." The record is a receipt that confirmed the types, quantities and payments of additional hay (in bundles) to the government by the farmers in the area for the You Year of Qianding Reign (1225). The printed content of the document was pre-inked onto the text so the individuals concerned could simply fill in the blanks-time of payment, the amount of taxes due and paid-during the tax registration process. This type of document was really a receipt issued at the submission of additional bundles of hays. It should be noted here that this format, whereby the pre-printed document with blanks to be filled out by hand, is of special cultural and material value in the history of books, history of printing and the history of economic institutions.

After all, the "official" (㣪) documents were public records and archives of the government for future legal references. The "household" (羓) document, on the other hand, was the receipt issued to the taxpaying farmers for their own references. This tale of two documents in Western Xia-one for public office and the other for private household - is a testament to the rigorous enforcement of the institutional procedures of operation and supervision at multiple levels of the Tangut tax system. In accordance with the Laws of Heavenly Prosperity, governments could not further impose levies on the taxpaying households in addition to the taxes specified on the land registers. However, these two documents both impose the burden of 'additional' bundles of hay onto the households. Given the dating of these manuscripts to the You Year of Qianding Reign (1225), the reference to "added 2 bundles" refers to taxes beyond those specified in the laws. These extrajudicial acts of tax collection reveal the existence and the extent of economic exploitation of the local poor at the bottom of the Tangut society. In the context of their own time, these materials also portray the social realities in an era of chaos and decline, near the end of Western Xia's imperial glory. ${ }^{32}$

32 Liang, Jihong. "Wuwei cang Xixixawen Qianding Younian Zengna Caokun Wenshu Chutan” [武威藏西夏文乾定西年增納草捆文書初探]: “A Preliminary Survey of the Documents on additional levies of hay in bundles, written in Tangut, dated to the You Year of Qianding, Preserved in Wuwei" in Xixiaxue [西夏學]: Tangut Studies, No. 10. Shanghai: Shanghai Ancient Works Publishing House, 2014. See also Chinese Collection of Tangut Manuscripts 16, pp. 390-393. 


\subsection{Documents of Land Taxes and Land-Ownership of Peasant Households}

There are some revelations on the conditions of land ownership in Western Xia in the shoushi self-reports mentioned above. Additionally, there is a large quantity of sources on the farmers' ownership of land in tax records. Some of the tax documents do not register the size of owned lands in straightforward statistics. But it remains possible, in most cases, to infer the amount of land owned based on how much tax is paid (given our knowledge of the tax rate, of course). For example, the manuscript Инв. No. 1755-4, an account of grain paid as taxes by households, reveals the farmland tax rate at 1 sheng of coarse assorted grains and 0.25 sheng of wheat per $m u$ of land. ${ }^{33}$ The Khara-Khoto manuscript Инв. No. 4808 mentioned above, including an account of liliu grain taxes and another of household tax payments, gives us the quantity of barley and wheat paid by these farming families. With these statistics, it is possible to infer the land ownership of these households:

One household, pays Barley 1 dan 1 dou 5 sheng, wheat 2 dou 8 sheng 7.5 ge; estimated land size: $115 \mathrm{mu}$.

One household, pays Barley 4 dou 3 sheng, wheat 1 dou 7 ge and a half, estimated land size: $43 \mathrm{mu}$.

One household, pays Barley 6 dou 7 sheng, wheat 1 dou 6 sheng 7.5 ge, estimated land size: $67 \mathrm{mu}$.

One household, pays Barley 1 dan 5 dou, wheat 3 dou 7 sheng and a half, estimated land size $150 \mathrm{mu}$.

One household, pays Barley 7 dou 5 sheng, wheat 1 dou 8 sheng 7 ge and a half, estimated land size $75 \mathrm{mu}$.

The fourth section in the same tax account features some slightly different types of foodstuff. The following are the ownership, conditions and use of land by the first five households on the list:

One household, pays coarse grains 2 dou, wheat 5 sheng, estimated land size $20 \mathrm{mu}$.

One household, pays coarse grains 1 dou, wheat 2.5 sheng, estimated land size $10 \mathrm{mu}$.

One household, pays coarse grains 1 dan 5 dou, wheat 3 dou 7.5 sheng, estimated land size $150 \mathrm{mu}$,

33 Shi Jinbo, 2005 (a). For the original, see Russian Collection of Khara-Khoto Manuscripts 13, p. 293 . 
One household, pays coarse grains 7 dou, wheat 1 dou 7.5 sheng, estimated land size $70 \mathrm{mu}$.

One household, pays coarse grains 6 dou, wheat 1 dou 5 sheng 2 ge, estimated land size 6o $\mathrm{mu}$ (this family registers the payment of $2 \mathrm{ge}$ more of wheat).

The manuscript fragments of the grain tax document $1755^{-4}$ records not only the amount of tax payment, but also the ownership of land by each household:

One household, owns land $150 \mathrm{mu}$, pays coarse grains 1 dan 5 dou, wheat 3 dou 7.5 sheng

One household, owns land $10 \mathrm{mu}$, tax 3 dou 7.5 sheng, coarse grains 4 dou, wheat 7.5 sheng.

One household, owns land $30 \mathrm{mu}$, tax 3 dou 7 sheng and a half, coarse grains 3 dou, wheat 7.5 sheng

One household, owns land $150 \mathrm{mu}$, tax 1 dan 8 dou 7.5 sheng, coarse grains 1 dan 5 dou, wheat 3 dou 7.5 sheng.

One household, owns land $70 \mathrm{mu}$, tax 8 dou 7 sheng and a half, coarse grains $7 \mathrm{dou}$, wheat 1 dou 7.5 sheng

One household, owns land $139 \mathrm{mu}$, tax 1 dan 7 dou 3 sheng 7.5 ge ...34

The wealthier farming families owned more than $100 \mathrm{mu}$ of land, the richest amongst whom boasted $150 \mathrm{mu}$ of owned land. The less opulent owned dozens of $m u$, with the least propertied family owning only $10 \mathrm{mu}$ of farmland. These numbers, once compared to those in land sale contracts, seem to match the sizes of land that were to be sold: $200,150,80,100,100,50,50$ and $30 \mathrm{mu}$. It may thus be inferred that these farmers sold all the land they owned. The 4 pieces of single-page land sale contracts were the documents of widow Yehe

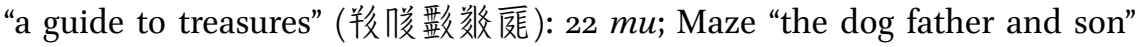

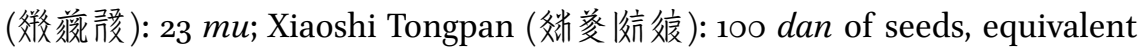
to about $1000 \mathrm{mu}$; and Liang Suyin (铮很㷇??): 10 dan of seeds, or $70 \mathrm{mu}$. It does appear that other than Xiaoshi Tongpan, the majority of Tangut farmers in Khara-Khoto owned somewhere between dozens to a hundred $m u$ of land.

There were also a number of households that owned large patches of farmland in the Khara-Khoto region of Western Xia. Some of them had more than one unit or stretch of land. The aforementioned Khara-Khoto manuscript Инв. No. 8203 refers to a family that owned four patches of land: the first bordered the new canal, where 7 dan of seeds were sowed; the second bordered the 
Lüyi Canal, where 6 dan of seeds were sowed; the third bordered Xipan Canal, where 7 dan of sees were sowed; the fourth was a piece of assorted land at the opening of a field, where 7 dan of seeds were sowed. Holding constant the rate of 1 dan of seeds per $10 \mathrm{mu}$ of land, this household owned $28 \mathrm{omu}$ of farmland. Manuscript Инв. No. 7893-9, another shoushi (self-reporting) document, also registers a household that owned four patches of land: the first connected to the Yang canal and bordered the land of a man named Yehe "the Exuberant at Heart," where 20 dan of seeds were sowed; the second was connected to the Daoli Canal, bordering the land of Liang "the Happy Realm," where 15 dan of seeds were sowed; the third was connected to the Lüyi Canal, which bordered the land of Yihe "the prosperous lady," where 10 dan of seeds were sowed; the fourth was connected to the Qihu Canal, which bordered the land of Liang Nianniyou, where 7 dan of seeds were sowed. In sum, the size of all owned lands was $570 \mathrm{mu}$ of land. ${ }^{35}$ The first family herein concerned had 6 members with multiple livestock. The second household boasted some political status, with 18 members and also some livestock. They were not the standard, everyday Tangut family, but affluent landlords with bountiful cultivation and possession.

\section{3}

\section{Poll Tax}

The Tanguts paid poll taxes, in addition to land, labour and hay duties. This tributum capitis, as the name suggests, was levied on each head of a resident in an area jurisdiction. The Khara-Khoto corpus of documents has yielded a number of poll tax accounts, the most exemplary and focused of which is perhaps the manuscript Инв. No. 4991.

The five poll tax fragments, registered from Инв. No. 4991-5 to 4991-9, are manuscripts written in the Tangut running and cursive script on $18 \mathrm{~cm}$-wide hemp papers. The length varies: $28.5 \mathrm{~cm}, 31.5 \mathrm{~cm}, 40.2 \mathrm{~cm}, 43.4 \mathrm{~cm}$ and $9.6 \mathrm{~cm} .{ }^{36}$ Amongst them, the manuscript fragment Инв. No. 4991-5 poll tax account registers numbers by the unit of households. Statistics on two and a half families are recorded in 16 lines of Tangut in the running and cursive script. The same expression, "one household," sets off the poll tax statement on each family, followed by the name of the head of the family, the demographic information of the household, and finally, the sum of taxes due and the distribution of this burden across individual men and women in the family.

35 Shi Jinbo, 2004 (a).

$3^{6} \quad$ Russian Collection of Khara-Khoto Manuscripts 13, pp. 322-324. 


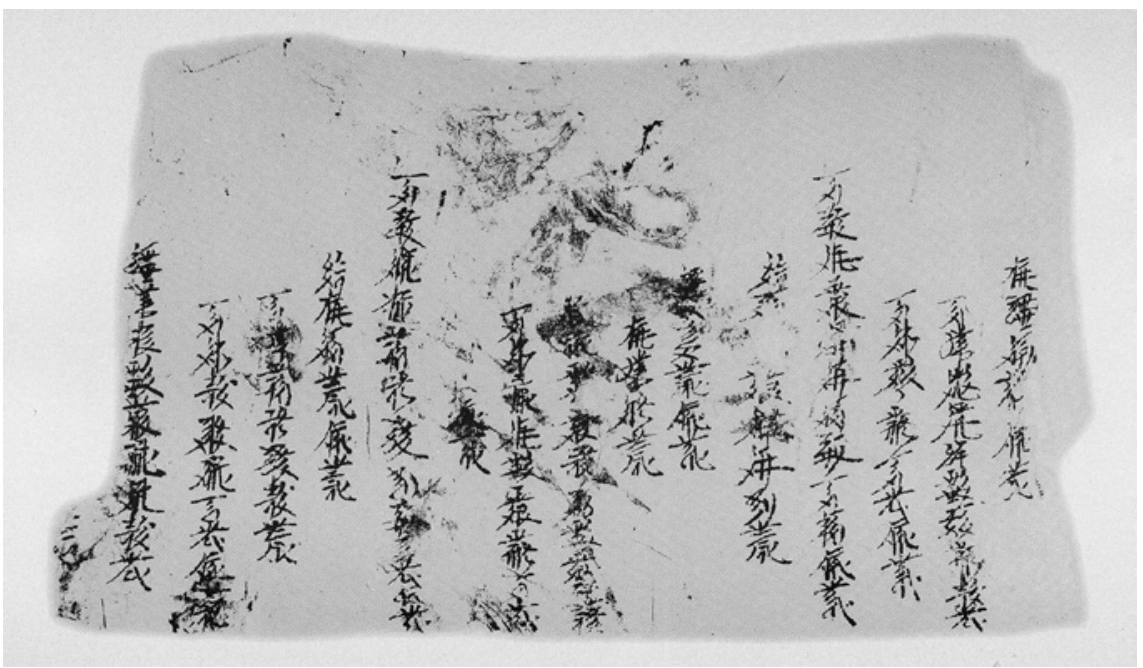

FIgURE 45 Инв. No. 4991-5: Poll tax account

Translation:

\section{Women 2 ...}

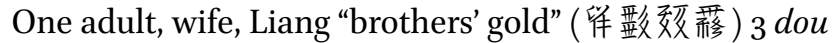

One junior, “maternal uncle's gold” (要政䔟) 1 dou 5 sheng

One household 张举? [kew śjow low], 4 members, 1 dan 5 dou

Male 1, 恠前? 3 dou

Female 3, 7 dou 5 sheng

2 adults, 6 dou

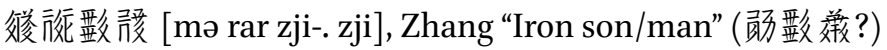

1 junior, Gao “the iron gold” (㹭前䔟), 1 dou

$$
5 \text { sheng }
$$

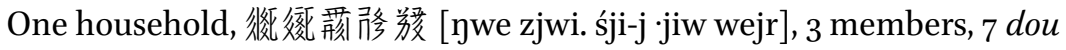
5 sheng

Male 2, 4 dou 5 sheng

1 adult, 荊铬誁 3 dou

1 junior, “Dog of the Triratna” (踥多敚婎) 1 dou 5 sheng

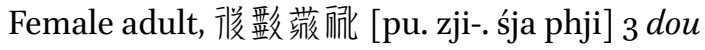




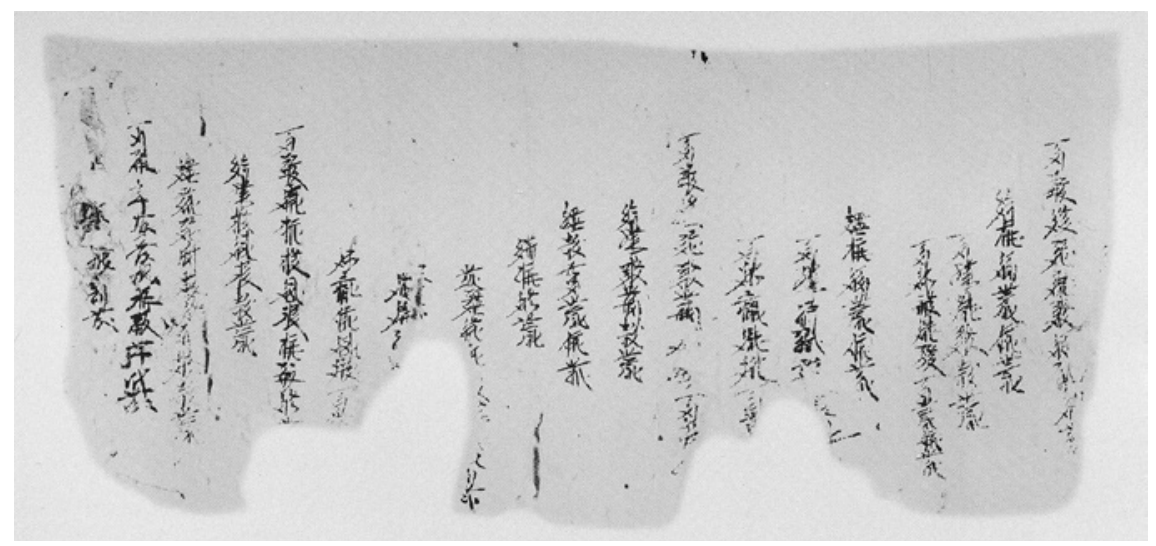

FIGURE 46 Инв. No. 4991-7: Poll tax account

Manuscript Инв. No. 4991-7 is also a poll tax account fragment on hemp paper, $18 \times 40.2 \mathrm{~cm}$, with 19 lines of Tangut - very much in the same format as Инв. No. 4991-5. Tax statistics on three out of four households have survived and remain legible. ${ }^{37}$

In spite of some missing and blurry parts, enough of this manuscript has survived for us to infer the tax records of the three families. The first household had four members. Of the two males, the adult paid 3 dou and the child 1 dou and 5 sheng. Of the two females, the adult and child paid taxes at the same rate. The second house also had four members, one adult male who paid 3 dou, three women, of whom two female adults paid 6 dou, and a girl paid 1 dou and 5 sheng. The third family had only two members, an adult couple who paid 6 dou.

It is easy to tell from the statistics in these two poll tax accounts that adults, regardless of gender, paid 3 dou per capita. Likewise, for the underage, in cases of both genders, the tax rate was 1 dou and a half.

Two other manuscript fragments, Инв. No. 4991-6 and Инв. No. 4991-8, are also poll tax accounts. The style of handwriting and quality of the paper suggest that the two pieces may have been connected as one manuscript. They are $18 \times 31.5 \mathrm{~cm}$ and $18 \times 43.4 \mathrm{~cm}$ in size with 16 and 19 lines of Tangut in the running script, respectively. These two poll tax accounts not only register the statistics by household, but also include a list of numbers on the poll taxes of an entire liliu district. ${ }^{38}$

$37 \quad$ Russian Collection of Khara-Khoto Manuscripts 13, p. 323.

$38 \quad$ Russian Collection of Khara-Khoto Manuscripts 13, pp. 323-324. 


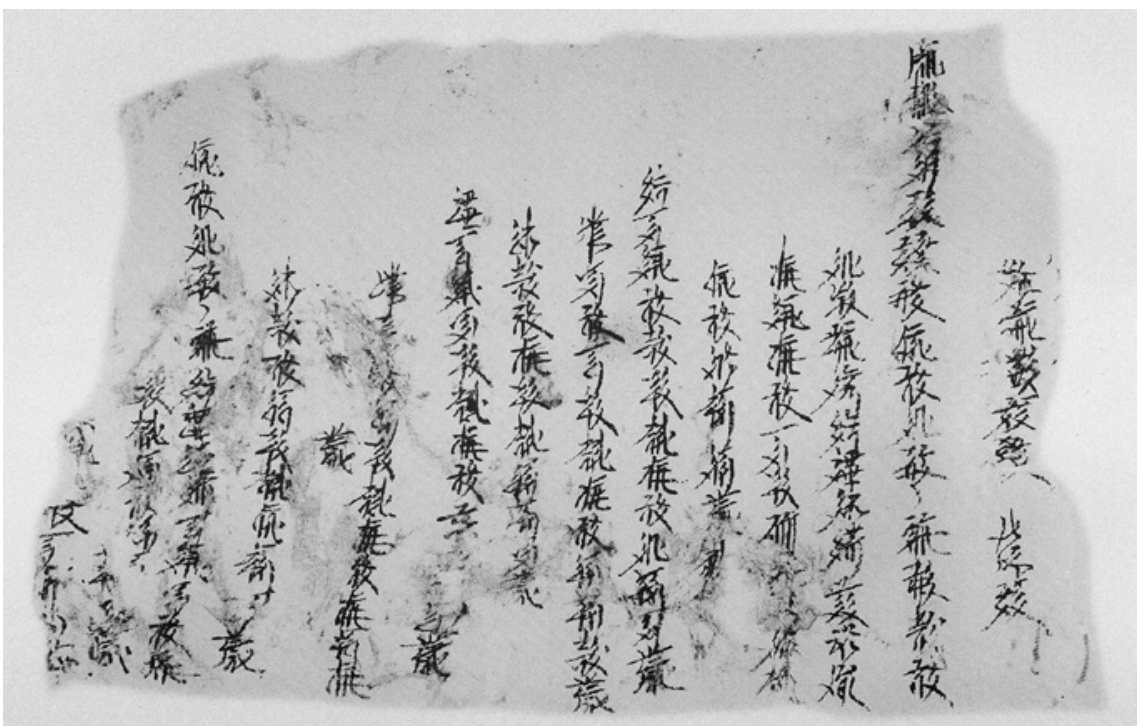

FIgURE 47 Инв. No. 4991-6: Liliu Poll tax account

The first line is probably the last bit of information left off from the previous liliu account. The following is a translation of the content of this manuscript, starting with the second line:

Liliu: Liang Suji (倠绡饺)'s Bureau, 59 households, in entirety, and 39 single men and women, adult and underage, total sum: 221 individuals' ? taxed grains, 56 dan 4 dou in number,

Males 113, grains 29 dan 1 dou

Adults 81, grains 24 dan 3 dou

Underage 32 , grains 4 dan 8 dou

Females 108, grains 27 [dan 3] dou

Adults 74, grains 22 dan 2 dou

underage 34, grains 5 dan [1] dou

59 households in entirety, men and women, adults and underage, 182 Individuals, grains $4[4 \mathrm{dan} 7] \mathrm{dou}$

Males adults and underage 87 , grains 21 dan 3 dou 


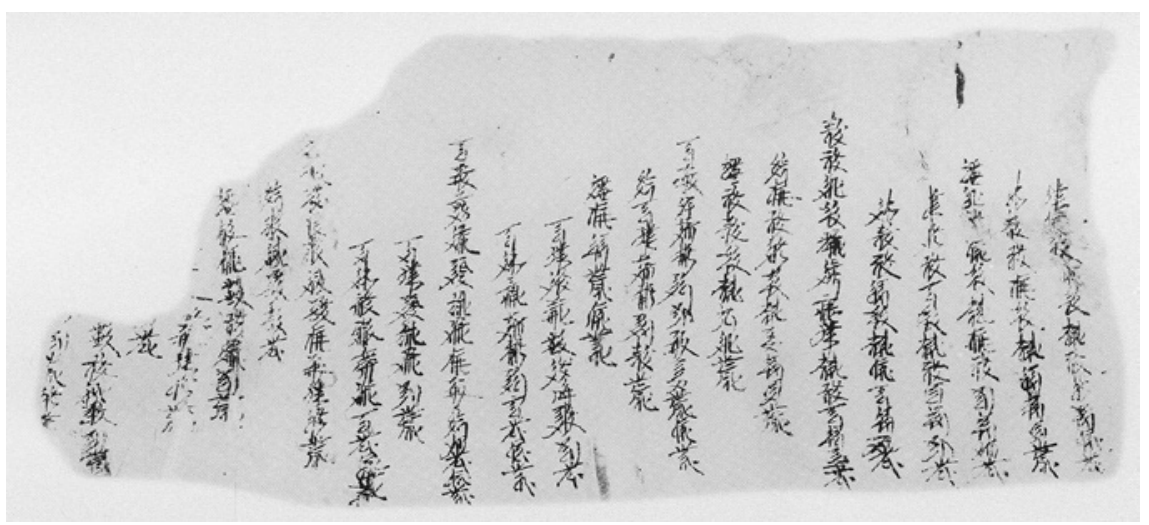

FIGURE 48 Инв. No. 4991-8: Liliu Poll tax account

Adults [55], grains 16 dan 5 dou

Underage 32 , grains 4 dan 8 dou

Females 95, grains 23 dan 4 dou

Adults 61, grains 18 dan 3 dou

Underage 34, grains $51^{39}$ dan 1 dou

39 singles, all adults, grains 11 dan 7 dou

Males 26, grains 7 dan 8 dou

Females, grains $[3]^{40}$ dan 4 dou

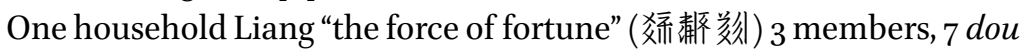
5 sheng

Male, 1 adult, "the force of fortune," 3 dou

Female, 24 dou 5 sheng

One adult, Maze "Treasure of the Old House" (㸚龍父拼绉), 3 dou

One underage female, "the force of fortune" 1 dou 5 sheng

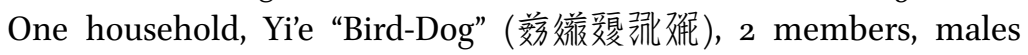
4 dou 5 sheng

One adult, "Bird-Dog" 4 dou

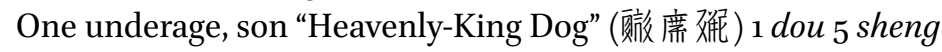
[One household]?? “Prosperous Twelfth Month" (格很瓶) 2 members, adults 6 dou

Male, "Prosperous Twelfth Month" 3 dou

Female, ??name? 3 dou

39 Interpretive edit: 夰 [lew] (one).

40 Resupply 彭 [so.] (three). 
The first part of the above text is the statistical account of the entire liliu residential district, including the person in charge of the liliu area, the total number of households, the number of single men and women, as well as the conditions of tax payments: the number of men and women, adults and children, and how much grain they paid. The account registered the adult and underage males and females in the 59 households, in addition to the 39 singles, as well as their due taxes. There was a total of 221 residents, who paid a sum of 56 dan and 4 dou grains as poll taxes. This information is followed by detailed accounts of demographics and tax payments by the units of households, including the concerned individuals' names, their relationships to the head of the family, their age — grown or underage — and the amount of grains they paid.

A comparison of the tax rate derived from the general account of the taxes paid by men and women, adults and children, and the rate generated from the statistics in the detailed household registers, points to the same conclusion on the standard of taxation: Distinction was based on age only, not gender. Each adult paid 3 dou, whereas a child paid 1 dou and a half. Armed with this tax rate, and holding it constant, it is possible to fill in the blanks for a lot of the other statistical charts generated from manuscript fragments, including information on missing tax numbers and demographics:

сHART 4 Инв. No. 4991-6 \& 8: Liliu poll tax account

\begin{tabular}{|c|c|c|c|c|c|c|c|c|c|}
\hline \multirow{3}{*}{$\begin{array}{c}\text { Categories } \\
\text { Person } \\
\text { count } \\
(\text { per })\end{array}$} & \multicolumn{4}{|c|}{59 households } & \multicolumn{4}{|c|}{39 singles } & \multirow{3}{*}{$\begin{array}{c}221 \\
\text { persons }\end{array}$} \\
\hline & \multicolumn{2}{|c|}{ Male, 87} & \multicolumn{2}{|c|}{ Female, 95} & \multicolumn{2}{|c|}{ Male, 26} & \multicolumn{2}{|c|}{ Female, 13} & \\
\hline & $\begin{array}{c}\text { Adult } \\
55 \\
\end{array}$ & $\begin{array}{c}\text { Minor } \\
32\end{array}$ & $\begin{array}{c}\text { Adult } \\
61\end{array}$ & $\begin{array}{c}\text { Minor } \\
34 \\
\end{array}$ & $\begin{array}{c}\text { Adult } \\
26\end{array}$ & $\begin{array}{c}\text { Minor } \\
\mathrm{o}\end{array}$ & $\begin{array}{c}\text { Adult } \\
13\end{array}$ & $\begin{array}{c}\text { Minor } \\
\text { o }\end{array}$ & \\
\hline \multirow{3}{*}{$\begin{array}{c}\text { Taxes paid } \\
(\mathrm{dou})\end{array}$} & 165 & 48 & 183 & $5^{1}$ & 78 & & 39 & & \multirow[t]{3}{*}{$564 \mathrm{dou}$} \\
\hline & 21 & 3 & & 34 & & 8 & & 9 & \\
\hline & \multicolumn{4}{|c|}{447} & \multicolumn{4}{|c|}{117} & \\
\hline
\end{tabular}

It can be inferred from these records that the administrative unit of liliu was in charge of setting up poll tax accounts for its households. The account first lists the overall account of the total poll taxes in the liliu, including the numbers of men and women, adults and children, as well as their due taxes. It then proceeds to register the demographic and tax statistics of each household.

In addition, manuscript Инв. No. 4991-6 and others also belong to the same type of poll tax account. Инв. No. $5^{223-2}$ is a poll tax account fragment with ink for handwriting practice on its back. 


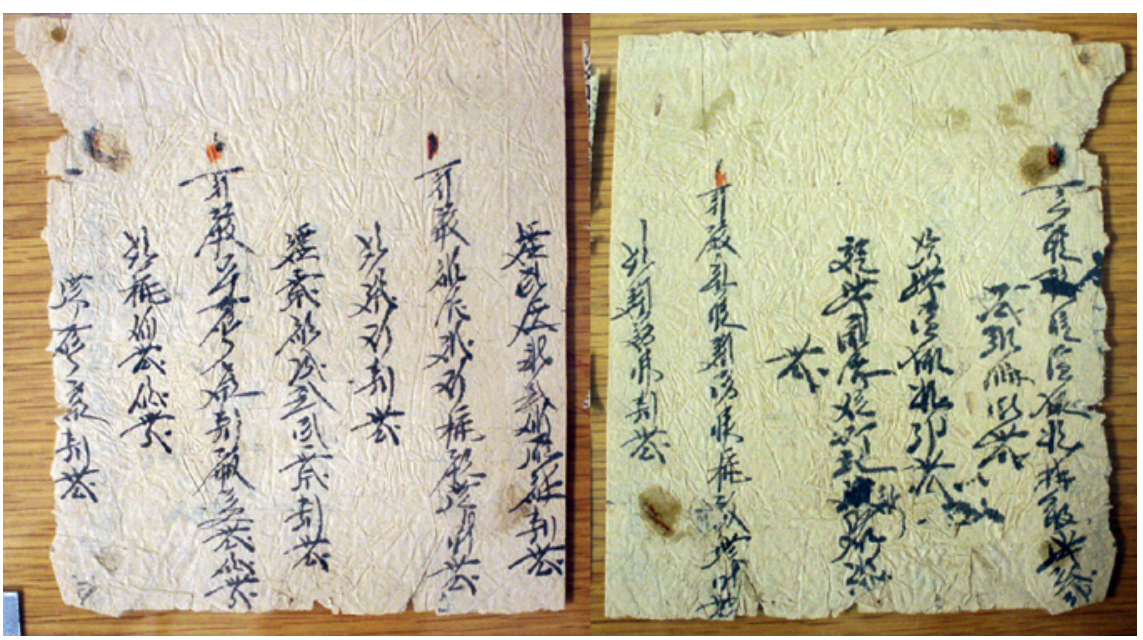

FIGURE 49 British 0324 (k.k.II.0285b): Poll tax account (front and back)

There are likewise poll tax accounts amongst the Khara-Khoto manuscripts housed at the British Library, such as Or. 1238o-o324V (k.k.II.0285b): two handwritten, $176 \times 145 \mathrm{~cm}$ remnant pages of a poll tax account, with 7 lines of Tangut in the cursive on each page. ${ }^{41}$

A literal translation as follows:

Female, wife, Lang 细形解 [xo tshji-j phiow 3 dou

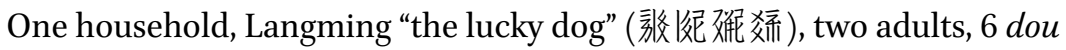

Male, "lucky dog" 3 dou

Female, [ka de_r] (Geyu) 微 [bie_j]? 3 dou

One household, 㸷 [ljow] (Liang) 後後蒘 [dju. dju. śjow], 3 members, 7 dou 5 sheng

Male 2, 4 dou 5 sheng

Adult, 蕧蕧偋 3 dou

$\cdots$

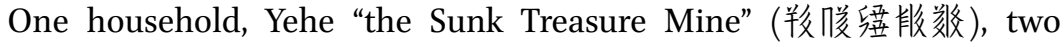
adults, each 3

dou, sum total $6 \mathrm{dou}$

Male adult, "Sunk Treasure Mine" 3 dou

41 British Collection of Khara-Khoto Manuscripts, p. 13o. It was originally named "New Laws of Year Hai" but here retitled "Poll Tax Account." 
Female, adult, wife, Qianyu “the blessed” (绞效煙胙茫) 3 dou

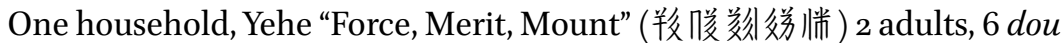
Male adult, "Force, Merit, Mount" 3 dou

Likewise, gender was not a variable in the determination of tax rate. Each adult, male or female, paid 3 dou in poll tax, whereas the child always paid half of that sum. The tax rate was exactly the same as we have derived from the poll tax accounts in Инв. No. 4991.

There are also overall accounts of poll taxes in the British Collection of Khara-Khoto Manuscripts. For example, the Or. 1238o-o344 (k.k.) poll tax account is a manuscript fragment written in the cursive, featuring total sums of poll taxes. ${ }^{42}$

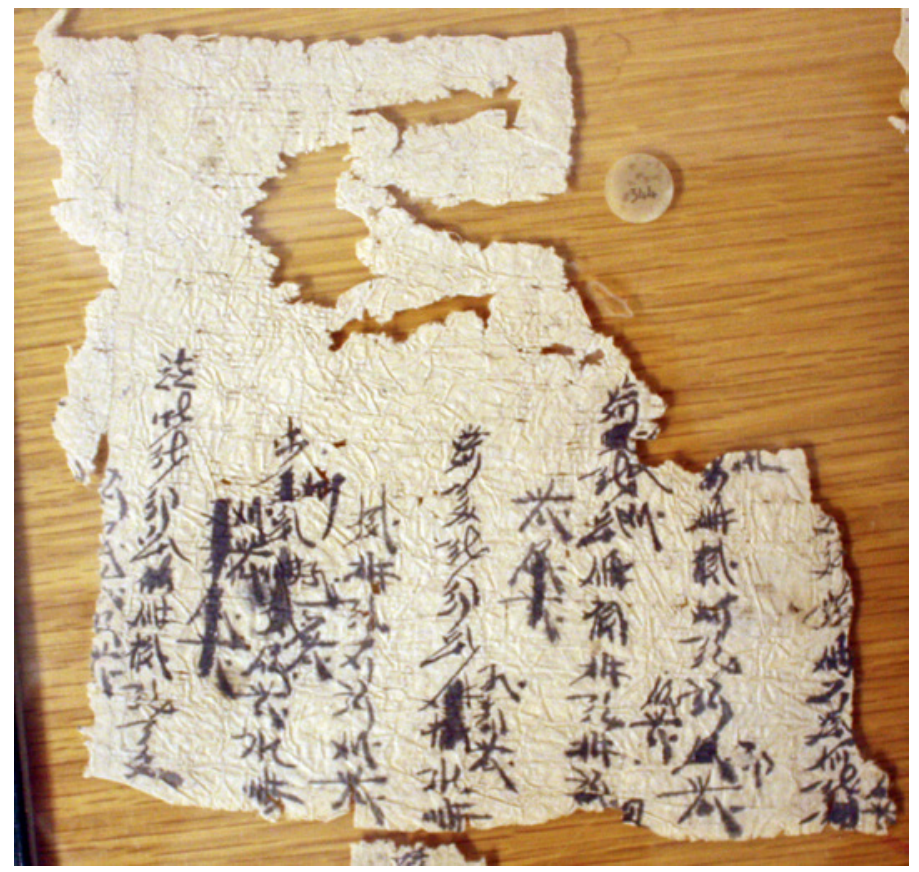

FIGURE 50 British 0344 (k.k.): Poll tax account

42 This image was photographed by the author of this book. See also British Collection of Khara-Khoto Manuscripts, p. 135. The document was originally named "A cursively handwritten piece of manuscript" but is given the caption "Poll Tax Account" in the context of this book. 
Translation:

... total: 140 dan

... total amount of grains: 40 dan 3 dou 5 sheng

Males: 79, total amount of grains, 22 dan 8 dou 5 sheng

Adults: 73 , each about 3 dou; total amount of grains, 21 dan 9 dou

Underage children 6, each around 1 dou 5 sheng, total 9 dou

Females: 63, total amount of grains, 17 dan 5 dou? sheng

This document also provides summary statistics of all households within a liliu. Due to the damages at the start, the total population is missing-nor is the total tax payment information available. But given the parts that are still legible, we know there were 79 men and 63 women, for a total population of 142. In sum, the men paid $22 \mathrm{dan}$ and $8 \mathrm{dou}$, and the women $17 \mathrm{dan}$ and $5 \mathrm{dou}$. We know that there was a total of more than 40 dan of grains paid as poll tax. It is also clear that in this context, taxation maintained the rate of 3 dou per adult and 1 dou and 5 sheng per child.

The Laws of Heavenly Prosperity provides ample documentations on the payment of grains as land taxes, but no traces have been uncovered on poll taxes. What is revealed in the record above unveils the reality of Tangut poll tax for the first time. As for whether the poll tax levied in the Khara-Khoto region was a temporary tax that fell outside the domain of the tax regime under the mandate of written laws, or a new form of tax that emerged as a result of new legislations posterior to the "Heavenly Prosperity" era, it is impossible to settle on a conclusion without the aid of further investigation.

But from what is known about the poll tax, the burden on peasants was not light at all. The 9 dou of grains due for a family of two adults and a child was the equivalent of land taxes, in coarse grains, levied on go mu of farmland. A typical Tangut household of relatively small size did not own more than $90 \mathrm{mu}$ of land. Therefore, this poll tax, many a times higher than the land tax, was obviously a heavy burden on the Tangut families. 


\section{Irrigation Tax}

Vast stretches of Tangut territory fell within the arid and rainless northwest of modern China. Prior to the restoration of Tangut power in this area, there had been a tradition of diverting the Yellow River for irrigation, near what came to be the centre of Dangxiang rule, between the Xing and Ling Prefectures of Western Xia. The Tanguts built upon excellent existing water conservancy facilities by extending water canals. These infrastructures provided the pillars of the Tangut irrigation system and further consolidated the status of this area as the backbone of Tangut agriculture. Inland, continental waterways such as the 'Black Water' — part of the Ejin River — flow through the "Black Water City," the site of Khara-Khoto in the northwest of Western Xia. The availability of water sources made it possible to undertake water conservation projects for the purpose of irrigation. Historically, this area had witnessed settled peasants and garrisoned troops opening up wastelands to grow grains. The Tanguts erected and expanded the city of Khara-Khoto against the natural obstacle of its perennial drought, not least encouraged by the nourishing presence of the Black River as a sufficient condition for developments in farming and pasturing. In this way, Khara-Khoto emerged as an oasis in the middle of deserts, a prosperous metropolis in northern Xixia, a formidable military stronghold that hosted the base for the Khara-Khoto Military Supervisory Commission, and a stout and spirited shield at the empire's border against enemies from the north.

Documents unearthed in Khara-Khoto endorse the view that historically, this area witnessed agricultural prosperity thanks to an irrigation system that depended on water canals. Amongst the manuscripts found in the Black Water City are two pieces of texts that are identified as records of irrigation taxes. These are primary sources that speak directly to the payments of taxes for the irrigation of farmlands under Tangut administration.

One of the documents is the "Account of Farmland Irrigation Тах," Инв. No. $1454-2 \mathrm{~V}$, a $15.7 \times 33.7 \mathrm{~cm}$ manuscript fragment with 14 lines in Tangut cursive. ${ }^{43}$ 


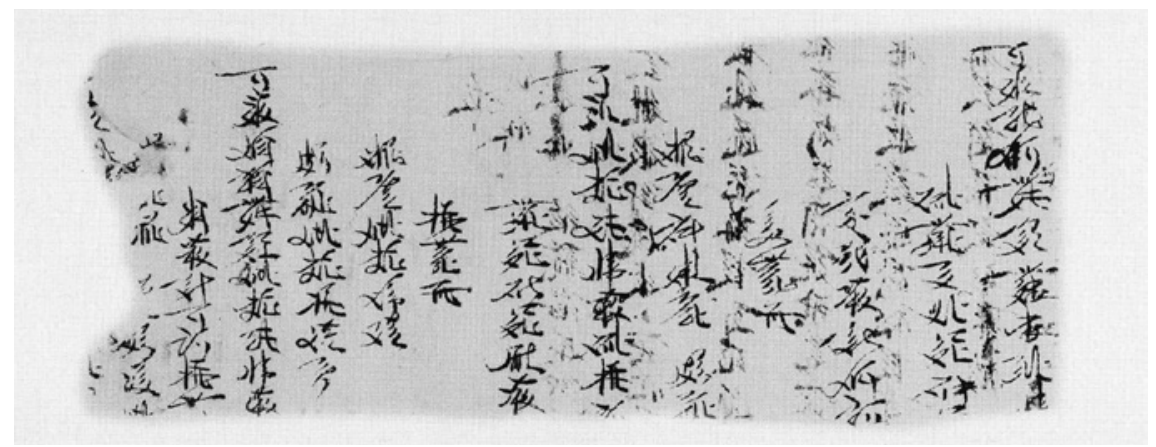

FIGURE 51 Инв. No. 1454-2V: Account of farmland irrigation tax

Translation:

One place, 14 (dan) place whither ......

Irrigation [yi] single ......

?? water tax 4 dan? dou

7 sheng and a half

Southeast Liang?? West

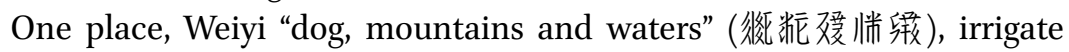
2 dan place whither

????? water tax? dou

2 sheng \& a half

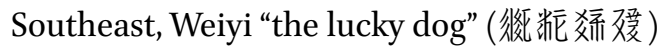

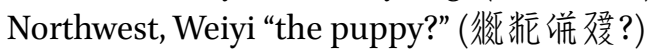

One place, 4 dan, place whither, Weiyi “dog, mountains and waters" ...

Daily water tax 1 dan 2 dou ...

east ... west ...

Due to losses, damages, and some overlapping strokes of ink written on both the front and the back of the paper, quite a few words remain illegible and untranslated. But the words pertaining to farming and irrigation are still recognisable. The document refers to water taxes levied on three patches of farmland. The statement on each piece of land begins with the two characters, "go toward, place" (Tangut: 带胶 [sjji- tji.]). It has been mentioned earlier that the Tanguts measured sizes of land by the amount of seeds sowed. In that case, the quantities of seeds and grains are labelled by the reference, "place sowed." (Tangut: 改数 [lju tji.]). Likewise, the parallel expression "place whither/to which xxx goes" also refers to land where a certain quantity of seeds is sowed and a certain amount of grains grown. Records of irrigation taxes rely on this 
CHART 5 Инв. No. 1454-2V: Account of farmland irrigation tax, chart

\begin{tabular}{llll}
\hline Location & Irrigation size & Irrigation tax & Irrigation tax/dan of seed \\
\hline$\#_{1}$ & 14 dan & 4 dan ?dou 7.5 sheng & Approx. 3 dou \\
$\#_{2}$ & 2 dan & ?dou 2.5 sheng & $?$ \\
$\#_{3}$ & 4 dan & 1 dan 2 dou ?sheng & Approx. 3 dou \\
\hline
\end{tabular}

сHART 6 Инв. No. 1454-2V: Account of farmland irrigation tax, chart (2)

\begin{tabular}{llll}
\hline Location & Irrigation size & Irrigation tax & Irrigation tax/dan of seed \\
\hline$\#_{1}$ & 14 dan & 4 dan 3 dou 7.5 sheng & 3.125 dou \\
$\#_{2}$ & 2 dan & 6 dou 2.5 sheng & 3.125 dou \\
$\#_{3}$ & 4 dan & 1 dan 2 dou 5 sheng & 3.125 dou \\
\hline
\end{tabular}

method to measure the amount of water used in irrigation and the corresponding quantity of tax to be paid. These documents also specify the locations of the land concerned.

Although some of the numbers in this statistical account of irrigation taxes are incomplete, it is possible to derive the missing figures from calculation, and even to determine the tax rate itself. From the statistics of location \#3, it may be inferred that to water a piece of land where 1 dan of seeds are typically sowed, one has to pay irrigation taxes in the amount of roughly 3 dou of grains or above. Given the integers and remainders in the tax account, if we set the rate of water tax at 3.125 dou per patch of land wherein 1 dan of seeds are sowed, then location \# $\#_{1}$ would be taxed 4 dan, 3 dou and 7.5 sheng; location \#2 would have to pay 6 dou and 2.5 sheng; and location \# 3 is liable for taxes in the amount of 1 dan, 2 dou and 5 sheng. These numbers would not only fit the integers and remainders of the water taxes in the three locations quite nicely, but also fill in the missing statistics to complete the chart.

It is possible to infer from these numbers that the water tax rate referenced in this record is 3.125 dou per unit of land for sowing 1 dan of seeds.

Another piece of document is the $12 \times 33.5 \mathrm{~cm}$ manuscript fragment Инв. No. 1781-1, an "Account of Farmland Irrigation Tax" with 15 lines of Tangut writings in the running style. 44

44 Russian Collection of Khara-Khoto Manuscripts 12, p. 313. 


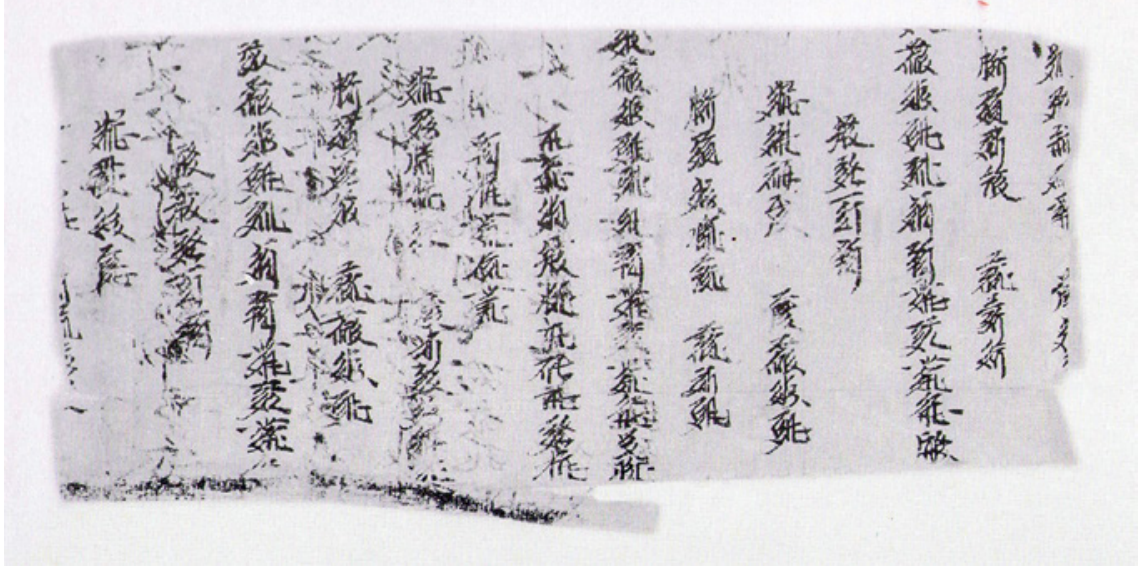

FIGURE 52 Инв. No. 1781-1: Account of farmland irrigation tax

Likewise, a number of factors have added obstacles to the interpretation of this text: damages at the beginning and the end, ink on both sides of the paper, and either light or blurred handwritings. A plausible translation is rendered as follows:

east???? South? ...

west slope, north, own land

One place Mount Cave Stream Irrigate 4 dan place whither [yi][six] [green]

Water Tax 1 dan

East: 炛 [phie dow dźjij] South: Stream from the Mountain Cave

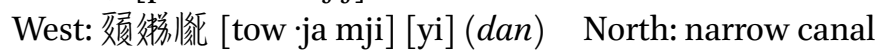
One place Mount Cave Stream Irrigate 9 dan place whither [yi][six]?

Half all day water to?? Half tax 2

dan 2 dou 5 sheng

East Nie Mount ?? South???

West many? (Temple) North Mount Cave Stream

One place mount cave stream irrigate 4 dan place whither [yi] ...

Water tax 1 dan

East ...

The document above also records three stretches of farmland with specified locations, the amount of water required for irrigation, and the tax levied on the water. 
CHART 7 Инв. No. 1781-1: Account of farmland irrigation tax

\begin{tabular}{llll}
\hline Location & Irrigation size & Irrigation tax & Irrigation tax/dan of seed \\
\hline$\#_{1}$ & 4 dan & 1 dan & 2 dou 5 sheng \\
$\#_{2}$ & 9 dan & 2 dan 2 dou 5 sheng & $\begin{array}{l}2 \text { dou } 5 \text { sheng } \\
\text { \# dou } 5 \text { sheng }\end{array}$ \\
\hline
\end{tabular}

Fortunately, the statistics of the three instances of water tax payments are complete. Therefore, it is easy to calculate the standard tax rate on irrigation to be 2 dou and 5 sheng of grains per piece of land where 1 dan of seeds are sowed.

Although the entire agricultural zone of Khara-Khoto relies on water irrigation of farmlands, it seems that different tax rates apply across the area. In the manuscript Инв. No. 1454-2V, a grain tax of about 3 dou and 1 sheng is levied on each unit of land in which 1 dan of seeds are sowed, whereas in tax record Инв. No. 1781-1, irrigation taxes in the amount of 2 dou and 5 sheng are imposed on each unit of land where 1 dan of seeds are sowed. The variance may have to do with the variable quantity of water required across the terrains.

Information on water taxes has also been found in socio-economic documents that are not explicitly and entirely tax receipts or records. For example, in the long scrolls of land transaction contracts excavated at the site of Khara-Khoto, seven out of eight land sale contracts mention such information at the end, where two to three Tangut characters appear below the tax numbers. Some mention "daily water" whilst others refer to "narrow water" or "narrow water [in] half." These are records on the variable conditions of water supplies for irrigation of the land concerned. It is possible that the size and scale of irrigation, hence the tax rate of water, varies from 'daily water' to 'narrow water' and to 'narrow water in half.'45

The Laws of Heavenly Prosperity (15) stipulates rules and regulations on the "affairs of canal-construction in the spring," "supervision of water and pasture-maintenance," "water canals," and "Miscellaneous Guilts and Crimes Related to Irrigation of Land," which concern the use of canals to irrigate farmlands. Despite some loss of information due to manuscript damages, much information on Tangut water use and conservation projects survives and remains. These chapters bring to light how the Tangut imperial machine mobilised task forces to build canals in the spring, patrol and examine the state of canals, collect bundles of hays and rafters, maintain the conditions of bridges 
and roads above the canals, and plant and protect trees by the sides of the canals. However, the question of irrigation taxes is seldomly addressed directly. Rather, it is for the most part the specification of the procedural flow of official documents in the Laws of Heavenly Prosperity that mentions taxes levied on the "dispatchment/distribution of water" (Tangut: 無鿏 [zji-_r wji.j]) in the

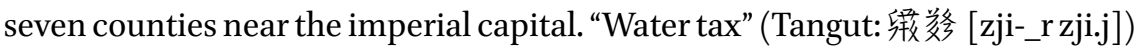

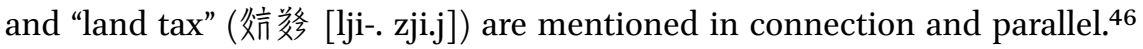
Furthermore, according to the Laws of Heavenly Prosperity's "Misbehaviours and Merits in Pressing for Payment":

The following is the method of pressing for irrigation taxes: from Mingsha, the Jurisdiction over the district of the Commander in Chief, to the various counties and vicinities in the area of the Imperial Capital, concerning the senior officials and the order-bearers in the Bureau of Transfer and Transportation, one officer is to be dispatched each year $\square \square \cdot{ }^{47}$

This "method" of levies on water for irrigation was applied in areas of the irrigable Hetao plains in the upper reaches of the Yellow River- the heart and veins of Tangut agriculture-on which the empire's populations depended. At the same time, agricultural taxation in these areas was the main source of government revenue for the state of Western Xia. In the Laws of Heavenly Prosperity, records and regulations on the taxes of land, labour, and hay abound, whereas specific items on taxing water are far less common. And yet, as a major and special category of agricultural tax, the levy of irrigation tax was widely practised in Western Xia. Accounts of farmland irrigation tax unearthed in Khara-Khoto provide us with detailed, authentic, and important primary sources on this type of tax in the Tangut Economy.

\section{5}

\section{Land Tax Increase and Grain Storage}

Thus far, Tangut documents found in the medieval city of Khara-Khoto have revealed records of farmland taxes and related taxes in labour and hay as well

$46 \quad$ Revised Laws of Heavenly Prosperity 9, "On Delays in Regulatory Duties," p. 319. The phrase was rendered 'case of family' in an earlier Chinese translation, but has since been revised to 'case of household.' In the original, little more than half of the character after 棂 [zji-_r] (water) remains legible. It has since been identified as 铬 [zji.j] (tax).

47 Revised Laws of Heavenly Prosperity 15, "On Guilt and Merit in Urging Tax Payments," p. 493. 
as poll taxes and irrigation taxes. When it comes to levying taxes on agriculture, Western Xia followed a rigorous workflow procedure and system of operation.

\section{1 $\quad$ Procedure of Levying Agricultural Taxes}

Since Western Xia levies taxed in kinds, typically grains, according to the size of farmland, an important task of the government in Khara-Khoto was to determine the area of land owned by each household in order to calculate the amounts of grains and hay to be paid. In addition to requiring the households to report the size of their land (in the unit of $m u$ ) and, accordingly, quantity of grains and hay to be paid on official land registers, the Laws of Heavenly Prosperity also stated the following:

The head of each household liable for taxation is obliged to report the time of farming, the number of oxen, and the amount of cultivation. The numbers in hu, dou, sheng, ge should be specified and written on a wooden board. Each household is to be given one piece of wooden board for this purpose. ${ }^{48}$

In other words, the Tangut government distributed wooden boards to households in order for families to report their land size, number of ploughing oxen, and amounts of grains and hay to be paid, with full publicity and transparency. The purpose of this law was not only to remind taxpayers of their own duties, but also to pre-empt both tax-evasion and abusive over-taxation.

China in the Central Plains had witnessed the maturation of a 'dual taxation' system since the mid-Tang period, whereby households were ranked and registered according to population and property, and taxed twice-once in the summer and then in the autumn. Instead, Western Xia collected taxes only once a year, according to the Laws of Heavenly Prosperity:

All the many kinds of taxes for which the households are liable to pay are specified and stated in the 'land register' book. The officials in charge of this matter in all the counties should, in due order, closely monitor and press the households for their due amount, and see to it that all payments are made within time limits. ${ }^{49}$

48 Revised Laws of Heavenly Prosperity 15, "On the Dispatchment of Junior Accounting Magistrate to Collect Taxes in the Form of Grains," p. 514.

49 Revised Laws of Heavenly Prosperity 15, "On the Miscellaneous Taxes of Irrigation for Farmland," pp. 507-508. 
The official book of registers, or 解 [dźjij] in Tangut, is also translated as 'register,' 'registration documents,' or 'land registers.' This book of records was maintained by the government, in part, to also keep track of land tax payments. The passage above stipulates that farming families pay the due amount of taxes in time, according to their land ownership as recorded in the land registers. The 'many kinds' of tax records belong to the book of the registers, but this part does not mention the time of tax payment, which can be found in the following passage from the Laws of Heavenly Prosperity:

If the officials in higher or lower bureaus of the counties do not report the statistics on the payments of various taxes in the areas of their jurisdiction to the Bureau of Transfer and Transportation, and submit the registers and receipts by the first day of November, they are to be tried on the charge of delay. If the submi ssion is overdue for one to five days, the punishment is thirteen strokes. If the submission is overdue for five to ten days, the punishment is imprisonment for three months. If the submissions are overdue for ten to twenty days, the imprisonment is 6 months long. If the delay is over twenty days, the guilty are to be imprisoned for one year. ${ }^{50}$

That is, county officials in Western Xia must submit the necessary books and receipts of taxes to the Department of Transfer and Transportation by the first day of the eleventh month, at the latest. Late submissions are subject to penalties. Therefore, the process of tax collection most likely took place and ended before November, or even October. It also means that the Tanguts paid their taxes in the autumn. Lying to the northwest of the Chinese Central Plains, most areas in Western Xia were colder than in territories of the Song Dynasty. Therefore, there was probably no more than one season for cultivation and for harvest. This would have especially been the case for Khara-Khoto, being further close to the north-western border of Western Xia, where the average temperature was lower than elsewhere in the country. Most of the grains were harvested once each year. What were 'summer grains' in the Central Plains, such as wheat, can only be harvested in Khara-Khoto in the seventh or eighth month in the lunar calendar. It is not surprising, then, that the Tanguts paid their taxes-in-kinds in the autumn.

Local magistrates had to issue receipts to the farmers and peasants who paid their taxes. According to the Laws of Heavenly Prosperity:

50 Revised Laws of Heavenly Prosperity 15, "On Urging the Payment of Taxes," p. 490. 
Let the magistrates in charge of urging payments of land taxes ride around the territories that fall under the jurisdiction of each Bureau of Transfer and Transportation, carrying white papers $\square \square$ stamped. The head of the household should claim the receipts and register on the white papers. The officer pressing for taxes should sign the papers in the presence of the owners of the receipts, in turn every fifteen days, to be examined by the staff in the Department of Transfer and Transportation. Any harassment against the heads of the household or solicitation of bribes from the families is strictly prohibited. Failure to register as required, in violation of the law, or failure to comply with the requirement of a signature by hand, will result in thirteen strokes. If the officers are bribed, then they are to be tried on the charge of corruption and contempt for law. ${ }^{51}$

It is no overstatement to say that the lawmakers of Western Xia designed a rather complete and comprehensive institutional system to pre-empt late payments, tax-evasions, and criminal activities on the part of magistrates susceptible to corruption or violation of law.

The Tangut government paid the highest regard and attention to agricultural taxes, which were the bloodline of the Tangut economy. Therefore, the imperial authority flexed its legal muscles and weaponised the laws to ensure a secure and smooth flow of the state's main source of revenue. To this end, the laws also specify the rewards and punishments for magistrates in charge of tax collection:

The officials in charge of urging tax payments should discern how much is paid and how much still remains unpaid, within the time limit, of all the kinds of land taxes in the case of tax-paying households. They should then divide the total sum of owed taxes into ten equal parts. Those who manage to exact nine out of ten, and leave one unpaid, are not to be charged. Those who receive eight out of ten, with two unpaid, are jailed for six months. Those who obtain seven out of ten, with three unpaid, are jailed for a year. Those who obtain six out of ten, with four unpaid, are jailed for two years. Those who obtain five out of ten, with five unpaid, are jailed for three years. Those who obtain four out of ten, with six unpaid, are jailed for four years. Those who obtain three out of ten, with seven unpaid, are jailed for five years. Those who obtain two out of ten, with eight unpaid, are jailed for six years. Those who obtain only one out

$5^{1} \quad$ Revised Laws of Heavenly Prosperity 15, "On the Miscellaneous Taxes of Irrigation for Farmland," p. 507. 
of ten, leaving nine unpaid, are jailed for eight years. Those who obtain none of the due taxes are jailed for ten years. Those who have collected all ten out of ten are rewarded the honour of a higher office, five taels in cash, and one $p i$ of coloured cloth. ${ }^{52}$

Given this system of reward and punishment, the magistrate would not be exempt from penalties if he managed to secure $9 \circ \%$ of the taxes that fall under his jurisdiction and supervision. Those who collected $80 \%$ or less of the full sum would be sentenced to six months to 10 years in prison, whereas savvy and dedicated magistrates who succeeded in procuring all due taxes for the government were rewarded cash, goods, and promotion. This institutional design, combining incentives with accountability, clearly promoted efficiency in tax collection.

Rare amongst all the law codes of dynastic empires in China, the Tangut Laws of Heavenly Prosperity is fastidious about the operational procedure of tax collection:

When it is time for the collection of various taxes, the junior accounting magistrate should sit at the gate of the storage house. The patrolling magistrates should sit by the side of the junior accounting magistrate. They should call the names of those paying grains as taxes, in due order, and then measure what they offer before taking them over. They should also issue receipts to the taxpayers, which label the total sums in $h u$ and dou and the signatures of the junior accounting magistrate. Any adulteration or falsification in the payment of grains is strictly forbidden. If the junior accounting magistrate and the patrolling magistrate from higher or lower offices are unable to check the amounts with accuracy, the local prefects in charge should take over the responsibility of supervision. If there is any violation of law-for instance, if those who did not pay are listed as having paid, or if there is inflation or falsification of the numbers-let the sum of the unpaid amount of grains be calculated, and let the culprit be tried on the charge of theft. If officials commit bribery, then the gravity of this offence is to be compared to the charge of 'Violation of Law and Corruption.' Whichever is more severe is to be applied to the culprit. If the concerned personality is not bribed, but rather committed errors in

52 Revised Laws of Heavenly Prosperity 15, "On Guilt and Merit in Urging Tax Payments," p. 493. 
examinations and calculations, he will be punished by the confiscation of a horse if an official, and by thirteen strokes if a commoner. ${ }^{53}$

More than an item of legislation, this passage contains a vivid portrayal of the actual and active scene of farmers paying their taxes. A junior accounting magistrate sits at the front gate of the government's storage house in the company of, but also under the watchful eyes of, a patrolling agent. The magistrate calls the heads or representatives of the households to come up to the front, in the order specified in the books of registers for grain tax payment. The taxpayers turn in their due taxes, which the magistrate then measures with tools, before receiving into the storage. Of course, the magistrate has to make sure there is no attempted misreporting or fraud throughout this process. The verbal description of this scenario furnishes us today with ample sources to reimagine the actual economic lives at the bottom end of a medieval society.

When local governments took in the grain taxes, magistrates prepared a new book. In Khara-Khoto, long documents running a hundred lines were quite common. These grain accounts such as the manuscripts Инв. No. 2568, Инв. No. $2851 \mathrm{~V} 2-6$, and Инв. No. $2851 \mathrm{~V} 8-14$ are, in fact, examples of such book registers for tax purposes. When these documents reached the Department of Transfer and Transportation, they were sent in turn to the Bureau of Review:

The staff members of the Bureau of Transfer and Transportation are responsible for delivering the record files, receipts, and other documents to the Bureau of Review within a month, in the time window between the first day of the eleventh month and the end of that month. If this task is not finished, and the work is overdue, the senior officials, the order-bearers, administrators, clerks, and agents are all charged on the various levels of misconduct in procrastination according to the same standards that hold officers in the county bureaus accountable, as specified above. ${ }^{54}$

As the files arrived at the Bureau of Review from the Department of Transfer and Transportation, there was a lapse of one month for the inspection process:

53 Revised Laws of Heavenly Prosperity 15, "On the Dispatchment of Junior Accounting Magistrate to Collect Taxes in the Form of Grains," pp. 513-514.

54 Revised Laws of Heavenly Prosperity 15, "On Urging the Payment of Taxes," pp. 490-491. 
The staff at the Bureau of Review arrive on the first day of the twelfth month with official papers for registration and the receipts. There is a month of time to examine these records. If these tasks are not completed upon the due date, and if the work, the senior official, order-bearer, administrators, clerks, and all the other staff members in the bureau are transferred to the office of the Bureau of Transfer and Transportation to be judged by the gravity of their misconduct and, accordingly, to be charged guilty of procrastination..$^{55}$

From local offices to the central government, the statistical compilation and analysis of taxes was not completed until the end of each year. Even after the process ended, magistrates across the board were responsible for seeking out and taking in the unpaid taxes, an additional labour which may as well extend into the next year.

\subsection{Burden of Tax on the Peasants}

Given the tax records of Western Xia that we have thus far considered in this chapter, it is possible to conclude that the Tanguts in the Khara-Khoto area paid three major types of taxes.

The first tax was in terms of grains, labour, and hay, according to the ownership of land (in units of $m u$ ). In most cases, the annual tax rate for farmland was 1 sheng of coarse grains and a quarter of wheat (o.25 sheng) per mu of land. Corvée labour was also measured by the size of owned lands, at the rate of 5 days of labour per $1 \mathrm{mu}-10 \mathrm{mu}$ of land; 15 days of labour per 11-40 $\mathrm{mu}$ of land; 20 days of labour per 41-75 $\mathrm{mu}$ of land; 30 days of labour per 75-100 $\mathrm{mu}$ of land; 35 days of labour per 10o-120 $\mathrm{mu}$ of land; and 40 days of labour per 120-150 $\mathrm{mu}$ of land. In addition, 1 bundle of hay was levied annually on each $m u$ of land.

In the Jurchen Empire of Jin, an ethnarchic economy contemporaneous to the later Western Xia, the state also levied taxes by land ownership, but twice: "in the summer, 3 ge of tax per $m u$; in the autumn, 5 sheng of tax per $m u$." ${ }^{6} \mathrm{In}$ sum, the Jin Dynasty imposed a tax of 5.3 sheng per $m u$ of land. Tax rates in the Song Dynasty varied across landscapes. In the Liangzhe Circuits- the Eastern and Western Zhe districts of modern-day Zhejiang, Shanghai, and southern Jiangsu taxes were paid in silk ( 3 chi and 4 cun $)$ and rice ( 1 dou, 5 sheng and 2 ge). The people of Fujian paid cash (between 3 and 4 wen) and rice (7-8 sheng). At a quick glance, it seems that in contrast, Western Xia set a rather low tax rate on agriculture. However, it should be noted that the Tangut $m u$ is smaller than

55 Ibid.

$5^{6}$ History of Jin Bk. 47. Book of Food and Goods, II. 
the Song $m u$. One unit of Song $m u$ was roughly equivalent to 2.4 Tangut $m u .{ }^{57}$ Besides, the Tanguts occupied some rough terrains in the northwest. The total size of arable lands and the per unit yield cannot be compared to the fertile plains of the Song Dynasty. Considering that the Tangut peasants bore additional burdens of other kinds of taxes, it should be said that the tax burden in Western Xia was not light at all.

The second type of tax was the poll tax account. As the name suggests, in line with the term's modern connotations, this 'tributum capitis' was levied on each individual resident of the empire, regardless of gender, but with some variances between adults and juniors. An adult paid 3 dou of taxes, whereas a child paid half of that amount- 1 dou and a half. But not unlike the land tax, the poll tax was levied on the household. Although no further details on the exaction of poll taxes are available in the Laws of Heavenly Prosperity, it suffices here to note that the burden of poll tax may not have been any lighter than that of land taxes.

The third category of tax was levied on the use of water for irrigation. Some land was taxed at the rate of 3 dou or more per dan of seeds; elsewhere, a different tax rate applied, at 2.5 sheng per dan of seeds sowed.

If a household of farmers was a family of four, with two adult parents and two children, and grew grains in a patch of land where they sowed 10 dan of seeds, then their precise burden of tax would amount to the following:

1. Given $10 \mathrm{mu}$ of land for 1 dan of seeds, 10 dan of seeds would be sowed in $100 \mathrm{mu}$ of land (roughly equivalent to $24 \mathrm{mu}$ of land by the standard of Song Dynasty). This family would have to pay land taxes in the amount of 100 sheng (or 1 dan) of assorted coarse grains, and 2 dou and 5 sheng of wheat.

2. Moreover, this family must pay 6 dou of grains as poll taxes for the 2 adults, and 3 dou for the two children- 9 dou in total. This sum of poll taxes was equivalent to taxes exacted on $90 \mathrm{mu}$ of lands. Some of the smaller families in Western Xia owned less than go mu of lands. In such cases, poll taxes higher than land taxes imposed by the government would definitely prove a major financial burden on smaller and poorer families.

3. Finally, the family would need to pay water taxes in order to irrigate their farmland. At the rate of $2.5^{-3}+$ dou of grains as taxes for 1 dan of seeds, this family is required to pay $2.5^{-3}$ dan of grains as taxes for their land, measured by 10 dan of seeds.

A total sum of these three taxes is anything between 4.4 and 4.9 dan of assorted grains, plus 2 dou and 5 sheng of wheat. In comparison, the Song Dynasty levied 
around 5 dan of grains on 24 (Song) $m u$ of land each year. And there is, of course, the 100 bundles of hay, and the likelihood of being called upon to travel afar to conduct corvée labour. In light of this, it must be said that this Tangut family in our hypothetical scenario pays a heavy duty to their government.

\subsection{Agricultural Taxes and Grain Storage in Western Xia}

The many tax records enumerated and explained above point to the consensus that the Tanguts levied taxes-in-kinds, rather than in cash, on agricultural production. The taxes came down to foodstuff. Farmland taxes, poll taxes and irrigation taxes were all paid in grains-either coarse, assorted grains or finer wheat. Hay, another medium of taxation, was also a tax in the form of real goods. Of course, there was always the additional option of paying tributes through physical labour.

The grain levies not only furnished the dining tables of the royalties, but also provided for the diet and salaries of all officials within the entire imperial bureaucratic apparatus. Moreover, a large number of professional soldiers in the army lived on government provisions, which were taxpayers' grains. For the Tanguts, whose agricultural economy was less advanced than in the Central Plains due to geographic reasons, grains claimed even greater symbolic and practical importance. Even as a large levy came into the exchequer's hands, Western Xia officials had to plan its carefully calculated use to guarantee sustainability over time, for it would have been foolish to consume as it went. This made it all the more critical to maintain proper preservation of these provisions; therefore, the keeping and storing of grains was a crucial political task. Western Xia included rules and regulations on grain storage in its fundamental law code. The Laws of Heavenly Prosperity required that the grains be thoroughly checked before warehousing:

When officials from local borders and from the district of the imperial capital arrive to collect all kinds of foodstuffs for the government, it is necessary to take care and caution to winnow the grains, in order that the finest foods and dry fruits enter the government's warehouses. ${ }^{58}$

There were also specific regulations on the construction of storage sites, where the foodstuffs exacted as taxes were held and preserved:

$5^{8} \quad$ Revised Laws of Heavenly Prosperity 15, "On the Dispatchment of Junior Accounting Magistrate to Collect Taxes in the Form of Grains," p. 510. 
The Military Supervisory Commission and the bureaus of the other Commissions should prepare the statistical records of the grains collected from borders and from the regions. They should designate a warehouse where there is ample timber, but it is necessary to place tiles on the structure. Where there is no timber, it is fitting to dig a cellar into a dry and firm ground, and then bake it with fire, to let it dry. Grain piles and the layering hay should be dense. On the top, the officials should spill three chi of dust, so as to avoid any damages to the government-owned grains. ${ }^{59}$

We know therefore that the Tanguts relied on two types of warehouses: storage houses above the ground and cellars underground. The Tanguts accumulated rich experiences in building facilities for the storage of provisions. Zhuang Chuo of the Song Dynasty offered a detailed introduction to Tangut modes of food storage along the Song-Xia borders in Shaanxi:

Given the high altitude of Shaanxi, and the vertical patterns of the earth, the government storage houses do not use other objects to store grains. Although wheat is the most difficult to endure, not a single granule is infected with pests throughout twenty years. Local residents would build a cellar within their land. These families would open up the ground, about the size of a well, and dig as deep as three to four chi. Given the limited capacity of the storage there, it is then expanded outward into its four borders. The earth is golden in colour, free of sand and stones. After burning, the twisted hay is nailed onto the four walls like ropes. A rich storage of grains reaches as much as several thousands of dan, and the quality is all the better in the progress of time. These people would use earth to firm up this opening. Right above the cellar, they still grow corns and cereals, and these grains would still be nourished as before. The only difference is that, now, once you knock on the ground, there is a sound. And once snow falls onto the earth, it is quick to melt. This is how you know that there is storage of grains underground. When enemies encroach upon the borders, this is how grain storages are discovered. And when our imperial armies reach the enemy camps, we also use this method to identify and seize these underground storages. ${ }^{60}$

59 Ibid., p. 513.

6o Zhuang, Chuo (Song Dynasty). Ji Lei Pian [雞肋篇]: Essays: Chicken Ribs. Beijing: Zhonghua Book Company, 1983 . 
The 'enemies' referred to in this rhetorical context refers obviously to the Tanguts. It is not difficult to see, based on Song narratives, that the Tanguts were perfectly aware of and versed in the art of underground storage popularly practised in the Shaanxi area. Rules and ordinances concerning the storage of foodstuff in the Tangut imperial law code shed similar light on this distinct method. All these materials point to the excellent standard and quality of Tangut storage and its local characteristics.

The arable lands of Western Xia yielded an abundance of grains, thus furnishing the empire with an opulence of taxes. The Laws of Heavenly Prosperity not only required that grains levied in various regions be turned over to the government, but also set the time limit according to the amounts of grains:

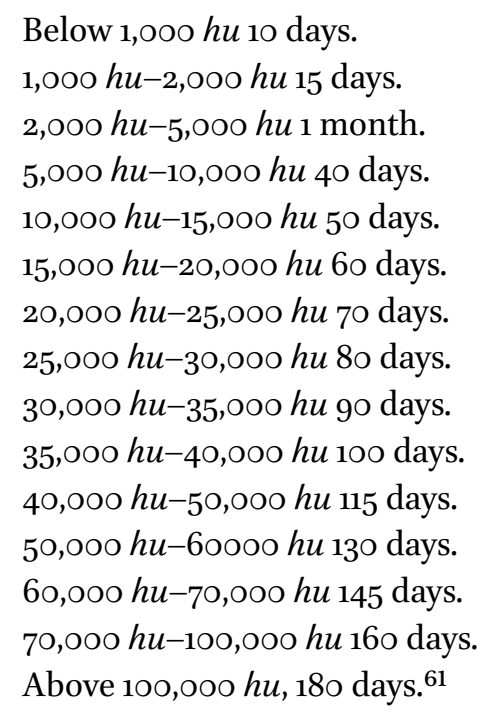

A district or area is required to turn over a maximum of 100,00o $h u($ dan $)$ to the central government. The implication therein is the Tangut practice of amassing and concentrating grains from the vast expanse of the empire into particular locations. And for this purpose, the government had to build a great number of storage sites. Tangut granaries were of various sizes and capacities, ranging from small storehouses of a volume somewhere within 5,00o hu (dan) supervised by only two staff members, to large constructions with more than 100,00o hu of grains overseen by one antou official in charge of 6 sili clerks. Some of the storage sites mentioned in the Laws of Heavenly Prosperity include

$61 \quad$ Revised Laws of Heavenly Prosperity 15, "On the Dispatchment of Junior Accounting Magistrate to Collect Taxes in the Form of Grains," pp. 510-511. 
the old and new Guanheishan granaries, the Central Commander's Land-Tax Granary, the Mingsha Military District Land-Tax Grain Storage, and the Woods and Nine Waters Land-Tax Grain Storage, etc. ${ }^{62}$

It is recorded in archives that in the midst of war, the Song army swiftly targeted Tangut granaries after occupying a new territory, sometimes capturing large sums of food supplies. In the seventh year of Da'an (1080), the Song general Li Xian conquered the Kangu area:

The great army passed by the valley of Kangu, which Bingchang unduly refers to as the 'imperial manor.' It houses an exceedingly large storage ... [I have] already dispatched my lieutenants to each lead a force to seize the grains, as well as bows and arrows for the defence of the city. ${ }^{63}$

Later, Song generals also seized a considerable amount of Tangut millet storages. ${ }^{64}$

As a counter-strategy to the Song seizure of granaries, the Tanguts resorted to relocating grain storages from areas about to fall to the enemies. For example, again in the seventh year of Da'an, (1080), Empress Liang "ordered that all civilians move the millet storages from the many districts" upon hearing news that the Song's Li Xian was about to breach the walls of Lanzhou. ${ }^{65}$

Western Xia boasted a mighty armed force in the hundreds of thousands, which rivalled the Song, Khitan and Jurchen soldieries for the duration of two centuries. Without a formidable economic engine, such a military machine would have been impossible to maintain. It is not difficult to see from the diverse documents mentioned above that the Tanguts had intention, the methods and ability to levy taxes and manage large storages, and in these ways, supported the operation of the government at home and the projection of power abroad.

62 Revised Laws of Heavenly Prosperity 17, "On Transfer and Transportation between Bureaus and Departments," pp. 529-534.

63 Extended Edition of the Zizhi Tongjian, Bk. 318, End of Tenth Year in the Winter of the Fourth Year of Yuanfeng, in Emperor Shenzong's reign (1081).

64 Xixia Shushi, Ch. 25. History of Song, Bk. 349, "Biography of Liu Changzuo"; Extended Edition of the Zizhi Tongjian Bk. 316. "Yiwei in the Ninth Month of the Fourth Year of Yuanfeng, in Shenzong Emperor's Reign. (1082).”

65 Xixia Shushi, Ch. 25. 


\section{Features of Agricultural Taxes in Western Xia}

A thorough analysis of the Khara-Khoto tax records reveals several key characteristics of Western Xia's tax revenues in the agriculture-based territories.

First, the Tanguts enacted a taxation system based on the size of land ownership. In other words, it was an institution of fixed taxation. In the Khara-Khoto region, for example, the tax rate was o.1 dou (or 1 sheng)/mu of assorted grains and 0.025 dou (or $1 / 4$ sheng) of wheat. Levying taxes based on land size was the most common tax system in the history of Chinese dynastic empires. The fact that the Tanguts inherited this system bears no small significance for our understanding of the agricultural economy in Western Xia.

Second, Tangut levies encompassed land, labour and forage (hay) taxes. That is to say, apart from paying the usual grain taxes by land size, it also fell on the landowners to contribute labour in days and hay in bundles. But the amounts of labour and forage were calculated in the same package as the grain taxes, by the standard of land size.

The social documents show that each year, based on the size of their owned lands, Tangut households contributed labour according to a scale of six levels: $5,15,20,30,35$, and 40 days, respectively. The labour force was directed for the most part to the construction, maintenance and management of canals in the spring. The nature, purpose and amount of labour services specified in these socio-economic records basically coincided with the relevant requirements in the larger area around the imperial capital, as found in the Tangut legal codex, the Laws of Heavenly Prosperity. Scholars therefore draw the conclusion that such tax rates once applied to not only residents of the capital, but also to peripheral territories such as Khara-Khoto.

Forage played a critical role in the inner life of the Tangut Empire. The government ceaselessly collected taxes in the form of hay bundles, which it then constantly supplied to the imperial cavalries in the time of war or burden animals used for long-distance transportation of goods and provisions. Another use of forage was the application of layers of hay for canal constructions and irrigation. The Khara-Khoto documents confirm that the Tanguts paid an annual tax of 1 bundle of hay per $m u$ of farmland. This was a peculiar form of taxation in Western Xia.

Third, tax-in-kind was the main form of agricultural taxation in Western Xia. Not unlike in the Central Plains, to submit taxes in the form of real goods or products remained the prevailing system of imperial tax collection at the time. It was supplemented, however, by tax in labour services. Because currency was not as well developed or commonly circulated in Western Xia as in the Central 
Plains, monetary tax payment is quite rare in the Khara-Khoto documents, compared to taxes-in-kinds and in labours.

Fourth, the poll tax was another key characteristic of the Tangut tax system. The social documents show that each Tangut adult was required to pay 3 dou of tax and each underage child was to pay $1.5 \mathrm{dou}$, regardless of gender. Unmentioned in the Laws of Heavenly Prosperity, this tax is known to us solely through these economic documents-indeed a major breakthrough in historical research on Tangut taxation. Such a 'head tax' in addition to the normal taxes listed in the Tangut law code must have proved a source of heavy financial burden for large peasant households with very few lands.

Fifth, irrigation taxes as mentioned in the economic documents-levies on the use of water for farming purposes-constituted another special taxation in Western Xia. On the one hand, such a tax reflects the prosperity of agricultural-hydraulic projects and the heavy dependence on canals for irrigation in the Khara-Khoto area. On the other hand, these manuscripts document the details of the water tax rates at various levels. Given the different amounts of water used at various agricultural sites in Khara-Khoto, water taxes also varied to different degrees. Lands were taxed at rates ranging from 3 dou and 1 sheng to 2 dou and 5 sheng per dan of seeds sowed. As a special form of agricultural tax, irrigation and water taxes were widely collected throughout the vast expanse of Tangut territories. Tax records excavated from Khara-Khoto are the only known extant primary sources on Tangut irrigation taxation. 